\title{
Amazon Nehri Havzası'nda Sürdürülebilir Sosyoekonomik Kalkınmayı Tehdit Eden Unsurlar
}

\author{
Hüseyin ŞAHBAZ1
}

\begin{abstract}
Özet
$\mathrm{Bu}$ araştırmanın amacı, drenaj alanı ve deşarj bakımından dünyanın en büyük akarsuyu olan, Amazon Nehri Havzası'nda sürdürülebilir sosyoekonomik kalkınmayı tehdit eden unsurların neler olduğunu belirlemektir. Araştırma kapsamında literatür taraması yapılarak konuyla ilgili veriler temin edilmiştir. Metin analizi yöntemiyle gözden geçirilen bu verilerden şu sonuçlara ulaşılmıştır: Brezilya başta olmak üzere Amazon ülkeleri, ilgili havzada çevresel açıdan büyük riskler taşıyan, devasa hidroelektrik santralleri (HES), tarım projeleri ve madencilik faaliyetlerini yapmış ve yapmak istemektedir. Bu kalkınma stratejisi aynı şekilde devam ettiği takdirde, dünyanın akciğerleri olarak nitelendirilen, Amazon Yağmur Ormanları'nın önemli bir kısmı yarım yüzyıl içinde yok olabilir. Ayrıca havzada hem çok sayıda hem de büyük ölçekte yapılan barajlar, ormanlık alanları sular altında bırakarak buraları hem metan gazı üreten ve hem de salan yerler haline getirmektedir. Bunların bir sonucu olarak havzada, doğanın ikazı mahiyetinde, birtakım olumsuz olaylar meydana gelmeye başlamıştır. Çok geç olmadan bu uyarılar dikkate alınmazsa, havzada yaşayanlar verilen tahribatın zararlı sonuçlarına afetler yoluyla daha belirgin bir şekilde maruz kalmaya bașlayacaktır. Afetlerin ekonomiye vereceği zarar da havzadaki kalkınmayı olumsuz bir şekilde etkileyecektir. $\mathrm{Bu}$ nedenle havza ülkelerinin, sürdürülebilir bir sosyoekonomik büyüme için, çok geç olmadan kalkınma stratejilerini bir kez daha gözden geçirmeleri faydalı olacaktır.
\end{abstract}

Anahtar Kelimeler: Amazon Nehri Havzası, Amazon Yağmur Ormanları, Sürdürülebilir Sosyoekonomik Kalkınma, Küresel Isınma, Havza Yönetim Planı, Güney Amerika

\section{Factors Threatening Sustainable Socioeconomic Development in the Amazon River Basin}

\begin{abstract}
The aim of this research is to determine the factors that threaten sustainable socioeconomic development in the Amazon River Basin, the world's largest river in terms of drainage area and discharge. Within the scope of the research, the literature was scanned and data on the subject were obtained. From these data reviewed by the text analysis method, the following conclusions

\footnotetext{
${ }^{1}$ Dr. Coğrafya Öğretmeni, Milli Eğitim Müdürlüğü, Afyonkarahisar

İlgili yazar e-posta/ Corresponding author e-mail: huseyiniyesuh@gmail.com ORCID No: 0000-0002-4808-0746
} 
were reached: Amazon countries, especially Brazil, have done and want to do huge hydroelectric power plants (HEPP), agricultural projects and mining activities that carry enormous environmental risks in the relevant basin. If this development strategy continues in the same way, a significant part of the Amazon Rainforest, which is described as the lungs of the world, could disappear in half a century. In addition, dams constructed both in numerous of and large scale in the basin leave the forested areas under water and make them both methane gas producing and releasing places. As a result of these, some negative events have started to occur in the basin as a warning of nature. If these warnings are not taken into consideration before it is too late, the inhabitants of the basin will begin to be exposed to the harmful consequences of the destruction more clearly through disasters. The damage of the disasters to the economy will also negatively affect development in the basin. Therefore, it would be beneficial for the basin countries to review their development strategies once again before it is too late for a sustainable socioeconomic growth.

Keywords: Amazon River Basin, The Amazon Rainforest, Sustainable Socioeconomic Development, Global Warming, Basin Management Plan, South America

\section{GİRIŞ}

Sürdürülebilirlik kavramı, bir toplumun, ekosistemin ya da sürekliliği olan herhangi bir sistemin işlerini kesintisiz, bozulmadan ya da sistemin hayati bağı olan ana kaynaklara aşırı yüklenmeden devam ettirebilme yeteneği olarak tanımlanabilir (Karaman, 1996: 102).

Kalkınma ise, bir ülkenin yapısal niteliklerinin olumlu yönde değişimidir. Kalkınma sürecinin ekonomik, sosyal ve insan olmak üzere üç elemanı bulunmakta ve bunlar ülkelerin gelişim uğraşlarında eş zamanlı olarak yürütülmektedir (Tolunay, Akyol, 2006: 116).

Sürdürülebilirliğe ilişkin kaygılar Malthus ve Jevons gibi kimi XVIII. ve XIX. yüzyıl iktisatçılarına kadar götürülebilse de "sürdürülebilir kalkınma" kavramının doğuşu XX. yüzyılda çevreye ilişkin kaygıların ortaya çıkışına rastlamaktadır (Yeni, 2014: 183).

Nitekim 1960'lı yıllarda çevreye verilen tahribatın boyutlarının algılanmaya başlanmasıyla tetiklenen çevre ve ekoloji hareketi, 1970'lerde uluslararası boyuta ulaşmış, 1983 yılında Birleşmiş Milletler (BM) tarafından Dünya Çevre ve Kalkınma Komisyonu (WCED)'nun kurulmasına sebep olmuştur. İlerleyen zamanda, bu komisyon tarafından, çevrenin kalkınmayla ilişkisinin kurulduğu ve sürdürülebilir kalkınma kavramının tanımlandığı 1987 Brundtland Raporu oluşturulmuştur (Özmehmet, 2012: 5).

Bu rapora göre sürdürülebilir kalkınma, biyosferin insan faaliyetlerinin etkilerini emme kabiliyeti tarafından getirilen sınırlamaların dikkate alındığı bir gelişme süreci olarak tanımlanmıștır. Başka bir ifadeyle bu kavram, gelecek nesillerin kendi ihtiyaçlarını karşılama yeteneğini ellerinden almadan, şimdiki neslin ihtiyaçlarının karşılandığı bir kalkınma süreci olarak da tanımlanabilir (URL 1).

Sürdürülebilir kalkınma açısından Güney Amerika Kıtası'na bakıldığında, havza büyüklüğü ve deşarj bakımından dünyanın en büyük akarsuyu olan, Amazon Nehri Havzası'nda yaşananların oldukça dramatik olduğu görülmektedir (Şekil 1). Zira bu akarsu havzasındaki ülkeler, Brezilya bașta olmak üzere, bir süredir çevresel açıdan büyük riskler taşıyan devasa ölçekte ve çılgınca bir kalkınma çabası içindedirler. 
Aslında Yeni Dünya'da doğal kaynakların hızla tüketiminin, Coğrafi Keşifler'in ardından İspanyol ve Portekizli kâş̧ifler tarafından, kıtanın kolonileştirilmeye başladığı zamana kadar götürmek de mümkündür. Hatta bu araştırmaya konu olan nehir havzasının adı bile bu dönemde Avrupalılar tarafından verilmiştir.

Nitekim 1541 yılında Amazon'u ilk keşfeden İspanyol asker Francisco de Orellana, bu nehir civarında içlerinde kadın savaşçlların bulunduğu aşiretlerle çatışmıștır. Orellana, bu kadın savaşçlları Yunan mitolojisinde geçen Amazonlara benzettiği için, nehre Amazon adını vermiştir. $\mathrm{Bu}$ isim, her ne kadar nehrin tamamı için söylense de, Peru ve Brezilya'da yalnızca nehrin belli bölümlerini kastetmek için kullanılır. Nitekim Peru'da Ucayali Irmağı ile Maranon'un birleşmesinden sonraki kısım Amazon olarak anılırken; Brezilya'daysa nehrin Negro koluyla birleşme yerine kadar olan kısma Solimoes, Negro'dan Atlas Okyanusu'na kadar olan kısmaysa Amazon denilmektedir (Rafferty, 2011: 174).

Deşarj bakımından dünyanın en büyük akarsuyu olması nedeniyle Amazon Nehri'nin kaynağı, kâşiflerin ve araştırmacıların asırlardır dikkatini çeken bir konu olmuştur. 2014 yılına kadar Amazon'un baş kaynağının Peru'daki Nevado Mismi Dağı üzerindeki Apurimac Nehri olduğu kabul ediliyordu. Ancak bir nehrin kaynağı, genellikle drenaj havzasındaki en uzak nokta olarak kabul edilmektedir. Buna göre belirtilen yılda yayımlanan bir araștırma, Amazon'un en uzak kolunun, kaynağını Peru'daki Cordillera Rumi Cruz Dağı'ndan alan, Mantaro Nehri olduğunu ortaya koymuștur. Sözü edilen araștırmayla Amazon Nehri'nin toplam uzunluğuna $92 \mathrm{~km}$ daha ilave edilmiştir (Contos ve Tripcevich, 2014: 27).

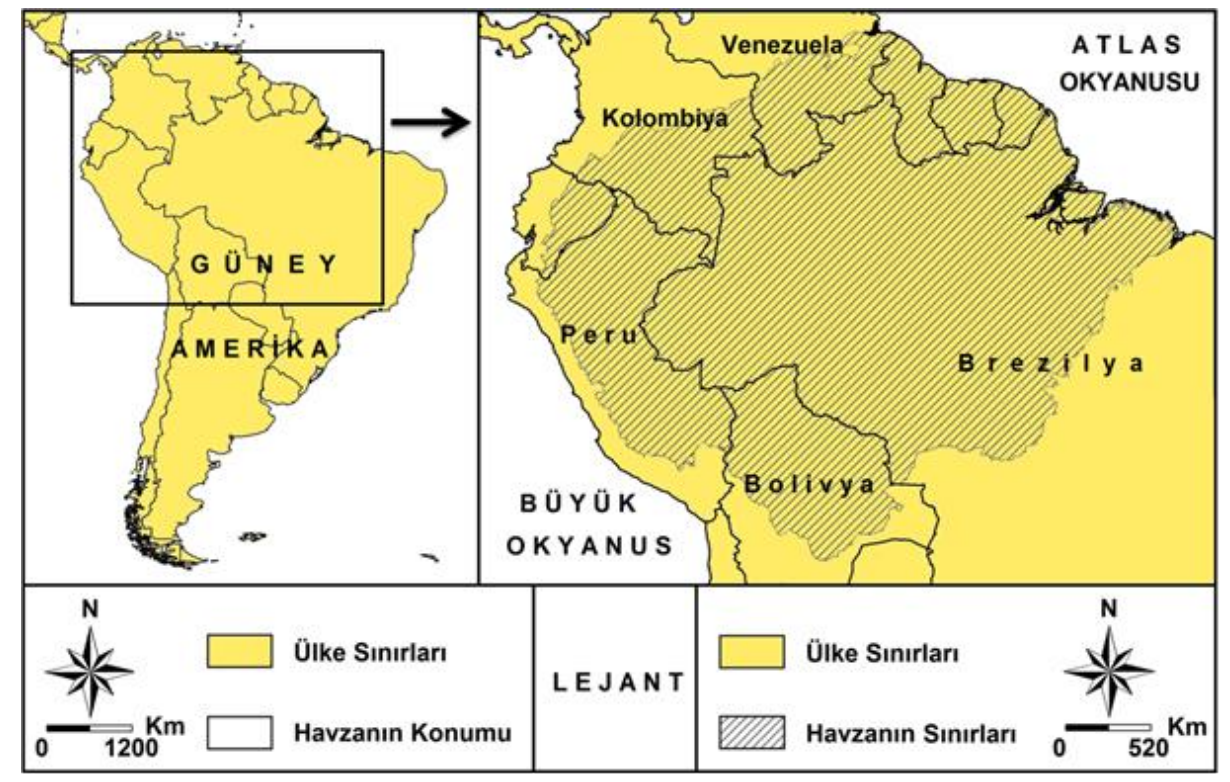

Şekil 1. Amazon Nehri Havzası'nın Konumu ve Sınırları Haritası

And Dağları'nın Peru'daki bir uzantısı olan ve ülkenin orta batısında yer alan Cordillera Rumi Cruz'a düşen yağışların akışa geçmesiyle oluşan Mantaro Nehri, GD istikametinde $45 \mathrm{~km}$ yol aldıktan sonra Junin Gölü'nün gideğeniyle birleşir. Bundan sonra GD istikametinde $400 \mathrm{~km}$ daha akışına devam eden nehir, keskin bir dönüş yaparak K-KB cihetine yönelir. Bu doğrultuda $122 \mathrm{~km}$ aktıktan sonra K-KD istikametine yönelerek $48 \mathrm{~km}$ boyunca yol alır. Bundan sonra tekrar GD'ye dönen Mantaro Nehri, 97 km sonra tekrar KD’ye yönelir ve bu doğrultuda 21 km akarak GD-KB istikametinde akışa sahip olan Apurimac ile birleşir. 
Apurimac ile birleştikten sonra Ene adını alan ve KB istikametine yönelen nehir, bu doğrultuda 27 km yol aldıktan sonra KD'ye dönerek $34 \mathrm{~km}$ akar ve tekrar KB'ye yönelir. Bu doğrultuda $111 \mathrm{~km}$ aktıktan sonra D-GD’ye yönelerek $67 \mathrm{~km}$ yol alan Ene Nehri, K-KB istikametine dönüp $78 \mathrm{~km}$ aktıktan sonra Atalaya kasabasının doğusunda Urubamba'yla birleșir. Bundan sonra Ucayali adıyla yoluna devam eden nehir, genel olarak K-KB istikametinde $1.050 \mathrm{~km}$ boyunca aktıktan sonra KD'ye yönelir. Bu doğrultuda $482 \mathrm{~km}$ boyunca yol alan nehir, Iqutos şehrine varmadan önce Amazon'u oluşturan diğer büyük kol olan, Maranon ile birleşir.

Bu birleşmeden sonra yoluna Amazon adiyla devam eden nehir, Iqutos şehrine kadar KD, bu şehirden sonra da D yönünde toplam $204 \mathrm{~km}$ aktıktan sonra KB-GD istikametinde akışa sahip olan kolu, Napo'yu bünyesine alır. Bundan sonra D-GD istikametinde $304 \mathrm{~km}$ boyunca akan nehir, Peru-Kolombiya sınırına gelir. İki ülke sınırını 103 km boyunca aynı doğrultuda çizen Amazon, Peru-Kolombiya-Brezilya sınırının kesişim noktasına ulaşır. Burada nehrin doğu yakasında birbirlerinin devamı olan Kolombiya'nın Leticia ve Brezilya'nın da Tabatinga şehirleri bulunmaktadır. Yine burada Amazon Nehri, Peru-Brezilya sınırını çizen bir diğer kolu, Javary'i bünyesine alarak ülkenin KB'sinden Brezilya topraklarına geçer.

Brezilya'da önce kuzeye, ardından da D-KD'ye yönelerek toplam $382 \mathrm{~km}$ akan Amazon burada, KB-GD istikametinde Kolombiya-Peru sınırını çizerek Brezilya topraklarına geçen kolu, Putumayo'yu alır. Bundan sonra KD-D istikametinde $425 \mathrm{~km}$ akan nehir, yine KB-GD istikametinde bir akışa sahip olan kolu, Japura'yı bünyesine alır. Japura'yla birleştikten sonra GD istikametinde $350 \mathrm{~km}$ akan Amazon, Coari şehri ve bu şehirle aynı adı taşıyan gölün kuzeyinde, KD-D istikametine yönelir. Belirtilen doğrultuda $220 \mathrm{~km}$ aktıktan sonra nehre, Purus kolu dâhil olur. Bundan sonra KD istikametinde $210 \mathrm{~km}$ akan nehir, Amazonas eyaletinin başkenti Manaus yakınlarında en büyük kollarından birisi olan ve aynı zamanda KB-GD istikametinde akışa sahip bulunan, Negro'yu bünyesine alır.

Manaus şehrinden sonra tekrar GD istikametine yönelen Amazon, $135 \mathrm{~km}$ bu doğrultuda aktıktan sonra en büyük kolu ve aynı zamanda GB-KD istikametinde akışa sahip olan, Madeira'yı bünyesine alır. Bundan sonra KD istikametinde yoluna devam eden nehre, $203 \mathrm{~km}$ sonra Uatuma kolu dâhil olur. Uatuma'yla birleşmesinden sonra GD'ye yönelen Amazon Nehri, 118 km sonra Parintins şehrinin kuzeyinde tekrar KD'ye döner. Bu doğrultuda akarken ikisi de sol kol olan Nhamunda ve Trombetas'ı bünyesine alır. Trombetas'la birleștikten sonra tekrar GD’ye yönelerek $175 \mathrm{~km}$ yol alan Amazon'a, Santarem şehri yakınında GB-KD istikametinde akışa sahip olan, Tapajos kolu dâhil olur.

Tapajos'la birleştikten sonra tekrar KD'ye yönelerek Atlas Okyanusu'na dökülünceye kadar bu doğrultuda akan Amazon, $584 \mathrm{~km}$ sonra sol kolu olan Paru ve bundan $41 \mathrm{~km}$ sonra da sağ kolu olan Iriri'yi bünyesine alır. Iriri'yle birleştikten sonra iki kola ayrılan Amazon'un sol koluna $65 \mathrm{~km}$ sonra soldan Jari Nehri dâhil olur. Akarsuyun sağ kolunun ise $235 \mathrm{~km}$ sonra yine Atlantik'e dökülen bir başka nehir olan Tocantins'le, Para adlı bir kol vasıtasıyla, bağlantısı vardır. Para adlı bu kol, Amazon'un ağız kısmında kıtasal bir ada olan Marajo'nun batı ve güneyinden dolaşarak Tocatins Nehri'yle birleşmektedir. Nihayet Amazon'un her iki kolu da Ekvator çizgisi üzerinde Atlantik'e dökülür (Şekil 2). Tüm bu yolculuk süresince nehir ana yatağının toplam uzunluğu, 6.250 km'yi bulmaktadır. Buna göre Amazon, Nil'den sonra dünyanın en uzun ikinci akarsuyudur. Atlas Okyanusu'nda seyreden açık deniz gemileri, Amazon ağzından bu nehir üzerindeki, Manaus Limanı'na kadar sokulabilmektedir. Ayrıca altları düz tekneler kullanmak suretiyle Amazon'un kolları boyunca seyahat etmek ve bu yolla Peru sınırına kadar ulaşmak da mümkündür (Ertek, 1991: 34).

Günümüzde And Dağları'nın doğusundaki Cordillera ve And'ın alt eteklerinin erozyonu, Amazon Havzası'ndan geçen tortu yükünün \% 99'undan fazlasını oluşturmaktadır (Santini vd., 2014: 320). Amazon'un taşıdığı devasa silt kütlesine rağmen nehrin herhangi bir deltası bulunmamaktadır. 
Bunda Atlantik'te meydana gelen gelgitlerin, nehrin getirdiği malzemeleri hızla okyanus tabanına doğru çekmesi etkilidir. Nitekim Amazon Nehri'nin ağız kısmında bu gelgitlerin yüksekliği, kimi zaman 6 m'ye kadar çıkmaktadır (URL 2).

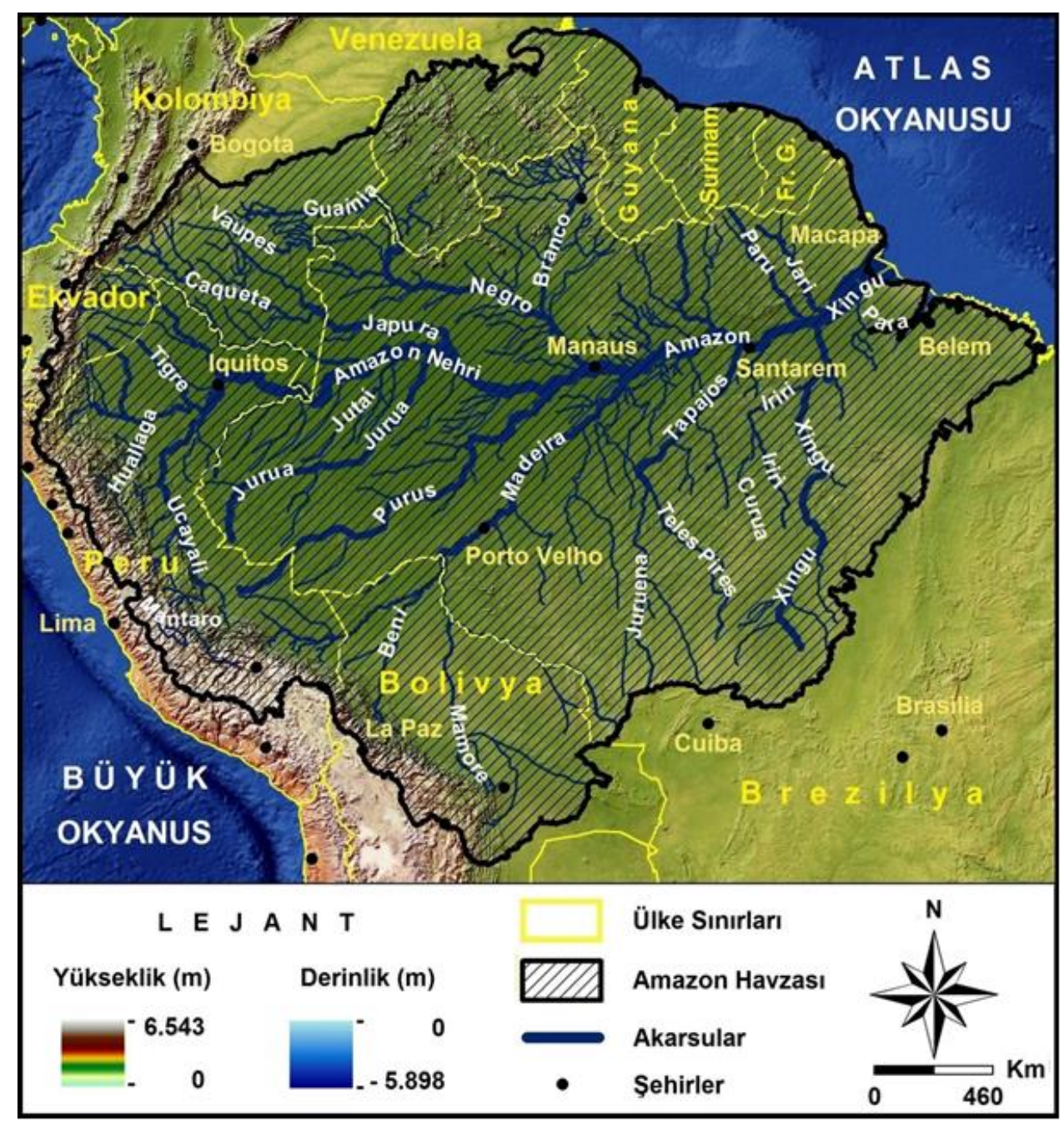

Şekil 2. Amazon Nehri Havzası ve Çevresinin Fiziki Haritası

Nehir ağzından yaklaşık 965 km içeride bulunan Obidos şehrinde bile okyanusun etkisi, akarsuda görülmektedir. Buna arazinin son derece yumuşak eğimli olması yüzünden gelgitin buralara kadar sokulması, neden olmaktadır. Bu olay, Amazon Halici'nde ilkbahar gelgitleri olduğunda meydana gelir ve nehrin sığ kollarında 1,5 ilâ 2,5 m arasında suların yükselmesine neden olduğu için belirgin bir şekilde hissedilir. Derinliği $7 \mathrm{~m}$ 'den fazla olan kollardaysa fazla hissedilmez. Amazon Nehri'nin hacmi, yılın, 6 ayında artarken diğer yarısındaysa azalır. And Dağları üzerine yağan karlar, ağustos ve eylül aylarında erimeye başlar, fakat bu etki akarsuda yavaş bir şekilde hissedilir. Kasımda yükselmeye bașlayan nehir, ocaktan mayısa kadar yükseltisi az olan sahalarda taşkınlar yaşanmasına sebep olur. Taşkın zamanlarında nehrin kimi yerlerinde seviye, 9 ilâ $15 \mathrm{~m}$ arasında yükselir. Havza büyüklüklerine bağlı olarak bu yükselme, nehrin güney kollarında fazlayken kuzey kollarındaysa düşük bir şekilde gerçekleşmektedir (Sailing Directions, 2004: 15).

Toplam 6.869.000 km²'lik bir havza alanına sahip olan Amazon Nehri, bu yüzölçümüyle sadece Güney Amerika'nın değil aynı zamanda gezegen üzerindeki en büyük drenaj alanına sahip akarsudur. Nitekim kıtanın \% 38,5'ini oluşturan Amazon Havzası, toplam 7 ülke tarafından paylaşılmaktadır. Bunlar içinde Brezilya, \% 69,1'lik bir oranla havzada en büyük orana sahip olan 
ülkedir. Bundan başka; \% 11,4'lük bir oranla Peru, \% 10,7'lik bir oranla Bolivya, \% 5,9'luk bir oranla Kolombiya, \% 2'lik bir oranla Ekvador, \% 0,8'lik bir oranla Venezuela ve \% 0,1'lik bir oranla da Guyana; havzayı paylaşan diğer ülkelerdir (Tablo 1).

Tablo 1. Amazon Nehri Havzası'nda Topră̆ı Bulunan Ülkeler (2003)

\begin{tabular}{|c|c|c|}
\hline Havza ülkesi & $\begin{array}{l}\text { Havza ülkesindeki } \\
\text { yüzölçümü }\left(\mathbf{k m}^{2}\right)\end{array}$ & Havza \%'si \\
\hline Brezilya & 4.746 .479 & 69,1 \\
\hline Peru & 783.066 & 11,4 \\
\hline Bolivya & 734.983 & 10,7 \\
\hline Kolombiya & 405.271 & 5,9 \\
\hline Ekvador & 137.380 & 2,0 \\
\hline Venezuela & 54.952 & 0,8 \\
\hline Guyana & 6.869 & 0,1 \\
\hline Toplam & 6.869 .000 & 100,0 \\
\hline
\end{tabular}

Aynı zamanda Amazon, yıllık yaklaşık $6.300 \mathrm{~km}^{3}$ 'lük deşarjla, dünyanın en büyük akışına sahip akarsuyudur. Buna göre nehrin deşarjı, global ölçekteki tüm akarsuların yaklaşık \% 15'ine tekabül etmektedir (Ray ve McCormick-Ray, 2004: 70). Bu devasa su akışı, Amazon Yağmur Ormanları'ndaki; yaprakları, tohumları, mantarları, hayvanları ve diğer çeşitli organik madde parçalarını, toprak ve mineralleri toplayarak Atlas Okyanusu'na boşaltır. Bu büyük besin akışının Atlas Okyanusu'ndaki yaşam üzerinde çok önemli bir yeri vardır (URL 3).

Güney Amerika'da Ekvator'un her iki tarafında bol yağış alan tropikal ormanlar bulunmaktadır. Amazon Havzası'nı baştanbaşa kaplayan bu ormanlar nedeniyle kıtanın iç kesiminde neredeyse tamamen boş denilebilecek alanlar bulunmaktadır (Ertek, 1991: 34). $5.665 .599 \mathrm{~km}^{2}$ büyüklüğündeki bu alan, gezegendeki mevcut tropikal ormanların yaklaşık yarısını oluşturmaktadır. Bunun yanında bilinen her 10 türden biri de bu alanda yaşamaktadır. Ancak küresel açıdan oldukça önemli olan bu ekosistem; tarım, hayvancılık ve çeşitli sebeplerle ağaç kesimi nedeniyle ormansızlaşma tehdidi altındadır (WWF, 2014: 21).

Amazon Nehri'nin Ucayali ve Maranon olmak üzere iki akarsuyun birleşmesiyle oluştuğuna yukarıda değinilmişti. Bunlardan Maranon, $360.050 \mathrm{~km}^{2}$ lik yüzölçümüyle nehir havzasının \% 5,2'sini oluşturmaktadır. Ortalama debisi, $14.700 \mathrm{~m}^{3} / \mathrm{sn}$ olan Maranon Nehri (Guyot vd., 2007: 314) Havzası'nda eşsiz bir biyoçeşitlilik vardır. Nitekim Peru'nun en büyük ulusal rezervlerinden birisi olan Pacaya-Samiria, Maranon ile Ucayali nehirleri arasında bulunmaktadır. Ancak bu benzersiz flora ve faunanın bir kısmı, tükenme tehlikesiyle karşı karşıyadır. Ayrıca Maranon Havzası'nın Peru'da kalan kısmında yüz binlerce ribeirinhos olarak adlandırılan nehir insanı, yiyecek ve geçimini bu akarsu ve çevresinden sağlamaktadır (URL 4).

Akaçlama alanı bakımından $350.500 \mathrm{~km}^{2}$ 'lik bir yüzölçümüne sahip olan Ucayali ise Amazon Nehri Havzası'nın \% 5,1'ini oluşturmaktadır (Santini vd., 2014: 320). Buna göre Amazon'u oluşturan Maranon ve Ucayali akarsularının ikisinin yüzölçümü, nehrin toplam havza alanının \% 10,3'üne tekabül etmektedir.

Drenaj alanı bakımından dünyanın en büyük akarsuyu olan Amazon, bazıların uzunluğu 1.600 km'den fazla olan 200'den fazla kol tarafından beslenmektedir (USGS, 1967: 3). Havza büyüklüğü açısından Amazon'un başlıca kollarıysa; Madeira, Negro, Xingu, Tapajos, Purus, Caqueta-Japara, Jurua, Putumayo-Iça, Trombetas, Napo ve Uatuma nehirleridir.

Bu kollardan havzanın kapladığı alan bakımından en büyüğü, $1.420 .000 \mathrm{~km}^{2}$ ile Madeira'dır. Nitekim tek başına Madeira, Amazon'un drenaj alanının \% 20,7'sini oluşturmaktadır. Bu nehrin 
ortalama debisiyse $31.200 \mathrm{~m}^{3}$ /sn'dir (UNEP ve IBAMA, 2002: 78). Madeira Nehri, And Dağları'nın Bolivya'daki doğu yamaçlarından kaynağını alan Beni ve Mamore kollarının birleşmesiyle oluşur. Bunlardan Mamore, 260 km Bolivya-Brezilya sınırını K-KB istikametinde çizdikten sonra Beni ile birleşir. Bundan sonra Madeira adını alarak iki ülke sınırını aynı doğrultuda $95 \mathrm{~km}$ daha çizerek Brezilya'ya geçer. Bu ülkede KD istikametine yönelen nehir, Brezilya'nın Rondonia eyaletinin başkenti olan Porto Velho'dan geçer ve nihayet Manaus şehrinin 135 km GD'sinde Amazon Nehri'ne dâhil olur.

Havza yüzölçümü bakımından Negro, Amazon'un ikinci büyük koludur. Yaklaşı 700.000 km²'lik bir alanla bu nehir, Amazon Havzası'nın \% 10,2'sini oluşturmaktadır. Aynı zamanda kimyasal özellikler bakımından Negro, dünyadaki en büyük "kara su" nehridir. Çözünmüş katıların ve asılı çökellerin konsantrasyonlarının son derece düşük olduğu nehirde, organik fazdaki asılı çökeltiler, igapo olarak adlandırılan ve mevsimsel olarak sular altında kalan bataklık ve sık ormanlardan nehre dâhil olmaktadır (Brinkmann, 1986: 3). Nitekim kara su nehirlerinin en önemli özelliği; ormanlık, bataklık ve sulak alanlardan yavaşça akmalarıdır. Bu nedenle suda çürüyerek akarsuya dâhil olan vejetasyon, nehre koyu bir renk vermenin yanında asidik bir özellik de kazandırmaktadır (Padmalal ve Maya, 2014: 17-18). Bu da neden söz konusu nehre, Latincede kara anlamına gelen, Negro isminin verildiğini açıklamaktadır.

Negro Nehri kaynağını, And Dağları'nın Kolombiya'nın doğusundaki uzantısı olan dağlık alandan, Guainia adıyla alır. Daha sonra Negro adıyla anılmaya başlayan nehir, Kolombiya-Venezuela sınırına gelir ve iki ülke sınırını GD istikametinde çizmeye başlar. Bu şekilde $164 \mathrm{~km}$ yol aldıktan sonra Negro'ya, yine Atlas Okyanusu'na dökülen bir başka akarsu olan Orinoco Nehri'yle bağlantısını sağlayan, Casiquiare Kanalı (veya Nehri) dâhil olur.

Casiquiare, Venezuela'da akmakta olan Orinoco Nehri'nin bifurkasyon yapması (yani çatallanıp kollara ayrılması) ve ayrılan kolun GB yönünde 345 km aktıktan sonra Negro'ya dâhil olmasıyla meydana gelmiştir. Böylece Orinoco ve Amazon nehir sistemleri, bu kanal vasıtasıyla birbirine bağlanmıştır. Casiquiare Nehri, bifurkasyon yoluyla iki havzayı birbirine bağlayan dünyanın en büyük akarsuyudur (Winemiller ve Willis, 2011: 226).

Casiquiare Kanalı'yla birleşmesinden sonra akışına devam eden Negro Nehri, 99 km daha GD istikametinde iki ülke sınırını çizerek Brezilya sınırına ulaşır. Buradan Brezilya'ya geçen Negro, önce batı, sonra da güney istikametinde akarak bir kolu olan Vaupes Nehri'ni bünyesine alır. Bu birleşmeden sonra GD’ye yönelen Negro, Manaus șehri yakınlarında Amazon'a dâhil olur.

Xingu Nehri, $508.046 \mathrm{~km}^{2}$ 'lik yüzölçümüyle Amazon Havzası'nın \% 7,4'ünü oluşturmaktadır. Bu akarsuyun ortalama debisi, $9.700 \mathrm{~m}^{3} / \mathrm{sn}^{\prime}$ dir (UNEP ve IBAMA, 2002: 78). Kaynakları Brezilya Kalkanı ile sınırlanan Xingu, sahip olduğu drenaj alanıyla Amazon'un en büyük temiz su koludur. Bunda nehrin, yüz milyonlarca yılda iklim olaylarının yumuşak çökeltileri yıkaması sonucunda ortaya çıkardığı, kristalimsi temel kayaçlar üzerinde akması etkilidir (Perez, 2015: 395).

Tapajos Nehri, 490.000 km²'lik yüzölçümüyle Amazon Havzası'nın \% 7,1'ini oluşturmaktadır. Bu akarsuyun ortalama debisiyse $13.500 \mathrm{~m}^{3} / \mathrm{sn}^{\prime}$ dir (UNEP ve IBAMA, 2002: 78). Brezilya'daki Mato Grosso Platosu'ndan kaynağını alan Juruena ve Teles Pires nehirlerinin birleşmesiyle oluşan Tapajos, Santarem şehri yakınında Amazon Nehri'ne dâhil olmaktadır.

Amazon'da en iyi korunmuş ortamlar arasında sayılan Tapajos Havzası, çok zengin bir bitki ve hayvan biyolojik çeşitliliğine ev sahipliği yapmaktadır. Bu nehrin havzasında; geleneksel yerli toplulukları, balıkçılar, küçük çiftçiler ve 10 da yerli grup yaşamını sürdürmektedir. Dolayısıyla Amazon'un ekolojik dengesi açısından bir mozaik niteliğinde olan bu havzanın (URL 5) korunması, büyük bir önem arz etmektedir. 
Purus Nehri, 375.458 km²'lik yüzölçümüyle Amazon Havzası'nın \% 5,5'ini oluşturmaktadır. Yaklaşık $3.380 \mathrm{~km}$ uzunluğundaki bu akarsuyun ortalama debisiyse $8.500 \mathrm{~m}^{3} / \mathrm{sn}$ 'dir (RíosVillamizar vd., 2017: 81). And Dağları'nın Peru'daki doğu yamaçlarından kaynağını alan Purus Nehri, KD istikametinde akarak Peru-Brezilya sınırına gelir. İki ülke sınırını 50 km çizdikten sonra da Brezilya'ya geçer. Bundan sonra da aynı doğrultuda akışına devam eden Purus Nehri, Amazon'un Manaus şehrine ulaşmasından 200 km önce, ona dâhil olur.

Japura Nehri, 248.000 km²'lik yüzölçümüyle Amazon Havzası'nın \% 3,6'sını oluşturmaktadır. Bu akarsuyun ortalama debisiyse $18.620 \mathrm{~m}^{3} / \mathrm{sn}^{\prime}$ dir (do Nascimento, 2015: 13). And Dağları'nın Kolombiya'nın GB'sine tekabül eden kısmından Caqueta adıyla akmaya başlayan nehir, GD istikametinde yol alarak Brezilya'ya geçer. Bu ülkede Japura adıyla anılan akarsu, önce doğu sonra da GD istikametinde akarak Amazon Nehri'ne dâhil olur.

Amazon Nehri ve kolları üzerinde, özellikle havzanın önemli bir kısmını elinde bulunduran ve ekonomik açıdan hızla kalkınabilmek için daha fazla enerji üretme gereksinimine ihtiyaç duyan Brezilya'da, çok sayıda baraj inşa edilmiştir.

Mevcut planlar gerçekleştiği takdirde, yakın bir zamanda yağmur ormanlarındaki baraj inşaatı dalgası, havzada büyük değişikliklere neden olacaktır. Global ölçekte bakıldığında dünyanın en büyük nehir sistemi olan Amazon'da az sayıda hidroelektrik santral (HES) barajı bulunmaktadır. Fakat 2011 yılında Brezilya'nın elektrik enerjisinin \% 10'undan daha azının temin edildiği Amazon'daki barajlara, 2040 yılına değin ülke enerjisinin yarısını karşılamaya yetecek kadar HES barajı inşa edilmesi planlanmaktadır (Tollefson, 2011: 160).

Ardında oluşan gölün yüzölçümü bakımından Amazon Havzası'nda inşa edilen barajların en büyüğü, Brezilya'nın Amazonas eyaletine bağlı Manaus şehrinin 146 km kuzeyindeki, Balbina'dır. Uatuma Nehri üzerinde yapılan ve 1989 yılında faaliyete geçen Balbina Barajı, yağmur ormanlarıyla kaplı $2.360 \mathrm{~km}^{2 \prime}$ lik bir alanı sular altında bırakmıștır. Hidroelektrik üretmek amacıyla inşa edilen bu baraj, aynı zamanda dünyanın şahit olduğu en büyük çevresel felaketlerden birine sebep olmuştur. Nitekim rezervuarındaki su seviyesi yükselip de çok geniş ve sığ bir topoğrafyayı sular altında bırakınca, yaklaşık 1.500 tane ada oluşmuştur. Yine WaimiriAtroari Yerli Rezervi'nin yaklaşık 1/3'ünü sular altında bırakarak buralarda yaşayan kabile üyelerinin yerlerinden edilmesine sebep olmuştur. Doğaya ve insanlara bu kadar zarar verilmesine karşın Balbina'dan elde edilen kazanç, yok denecek kadar azdır. Nitekim kurulu güç kapasitesi 250 MW olan Balbina Barajı'ndan elde edilen ortalama elektrik, sadece 112,2 MW'dir (Fearnside, 1991: 204).

Gerçekten de topoğrafyanın düz ve drenaj havzasının küçük olması nedeniyle, barajda oldukça az elektrik üretilebilmektedir. Sular altında kalarak çürümeye başlayan bitki örtüsü nedeniyle sığ rezervuarda, türbinleri korozyona uğratan asidik ve anoksik su ortaya çıkmıştır. Suyun bekleme süresinin bir yıldan daha uzun olduğu barajın rezervuarında, sayısız durgun bölge vardır. Devlet sübvansiyonları nedeniyle çok hızlı bir şekilde büyüyen Manaus şehrine elektrik tedarik etmek amacıyla inşa edilen Balbina, ormanın potansiyel kullanımının kaybedilmesine de sebep olmuştur. Sonuçta Balbina, gerek Brezilya'ya ve gerekse bu tür altyapılara kredi veren uluslararası finansman kuruluşlarına, baraj inşasına karar verme sürecinde nelere dikkat edilmesi gerektiğini gösteren kötü bir örnek olmuştur (Fearnside, 1989: 401).

Dahası tropik bölgelerde inşa edilen baraj rezervuarlarının, atmosfere önemli miktarda metan gazı saldığı da bilinmektedir (Kemenes vd., 2007: 1-5). Nitekim tropikal barajlardan kaynaklanan sera gazı emisyonları, biyokütle ayrıșmasıyla bakteriler tarafından su altında üretilmektedir. $\mathrm{Bu}$ barajlarda ağırlıklı olarak üretilen gazlar; azot, karbondioksit ve metandır. Baraj rezervuarlarındaki ana gaz kaynağı, temelde karbondioksit ve metan üreten, otonom ve allokton 
organik maddenin bakteriyel ayrışmasıdır. Ve metan gazı salınımına sebep olan bu barajlardan biri de Balbina'dır (Rosa vd., 2004: 9-10).

Çeşitli gazların küresel ısınma potansiyelini ortaya koymak için belirli bir periyotta (ki bu süre genellikle 100 yıl olarak alınır) onların ne kadar karbondioksite karşılık geldiğinin belirtilmesi, standart bir uygulamadır. Bu konuyla ilgili yapılan ölçümler, 1 ton metan gazının 25 ton karbondioksit kadar küresel ısınmaya sebep olduğunu ortaya koymuştur (UNEP, 2010: 9). Buna göre metan emisyonun çok daha kısa bir sürede gezegen atmosferinde ısınmaya sebep olacağı yadsınamaz bir gerçektir.

Yapılan bir çalışmayla Balbina Barajı'ndaki metan emisyonları, akış aşağısındaki türbinlerin çıkışında yapılan düzenli gaz ölçümleriyle ve rezervuardaki difüzif kayıpların tespit edilmesi yoluyla hesaplanmıştır. Buna göre sadece barajın akış aşağısında ölçülen yıllık emisyon miktarının, merkezi Amazon taşkın yatağından salınan tüm metanın \% 3'üne karşılılk geldiği tespit edilmiştir (Kemenes vd., 2007: 1-5). Bu da Balbina'nın neden dünyanın en kötü HES barajlarından birisi olarak nitelendirildiğini açıklamaktadır.

Ardında oluşan gölün yüzölçümü bakımından havzada inşa edilen ikinci baraj, Samuel'dir. Nitekim Madeira Nehri'nin bir kolu olan Jamari üzerinde inşa edilen bu barajın rezervuar alanı, $540 \mathrm{~km}^{2}$ 'dir. Samuel Barajı, Brezilya'nın Rondonia eyaletinde ve Porto Velho şehrinin yaklaşı 50 km doğusunda bulunmaktadır. 1989 yılında tamamlanan Samuel'in HES kapasitesiyse 216 MW'dir. 238 çiftçiyi yerinden eden bu baraj rezervuarının çevreye verdiği zarar büyük olmuştur. Nitekim Samuel'in inşasından sonra oldukça geniş bir orman alanı sular altında kaldığı için barajdan elde edilen elektrik, petrolden daha fazla sera gazı emisyonuna sebep olmaktadır (Fearnside, 2005: 1-2).

Nehrin Madeira kolu üzerinde yüzölçümü bakımından inşa edilen en büyük baraj, Jirau'dur. Bu baraj, Rondonia eyaletinin başkenti Porto Velho kentinin $120 \mathrm{~km}$ yukarısında inşa edilmiştir. 2016 yılının sonunda tamamlanan bu Jirau, $63 \mathrm{~m}$ yüksekliğinde ve $1.500 \mathrm{~m}$ uzunluğundadır. Ardında $361,6 \mathrm{~km}^{2}$ yüzey alanına sahip bir göl oluşturan baraj, milyonlarca Brezilyalıya enerji sağlamak amacıyla inşa edilmiştir. Barajın HES'inin elektrik enerjisi üretim kapasitesiyse 3.750 MW'dir (URL 6).

Yine nehrin Madeira kolu üzerinde ve Brezilya'nın Porto Velho şehrinin hemen yakınında inşa edilen Santo Antonio, ardında oluşan gölün yüzölçümü bakımından bir diğer büyük barajdır. Nitekim 2012 yılında tamamlanan bu barajın ardında 271 km²'lik bir göl oluşmuştur. Söz konusu barajın toplam hidroelektrik güç kapasitesiyse 3.568 MW'dir (URL 7).

Ancak gerek Santo Antonio ve gerekse Jirau, Brezilya'da çevre korumanın zayıflatıldığı kötü birer örnek olmuştur. Nitekim yapılan siyasi atamalar aracılı̆̆ıyla, çevresel etki değerlendirmesinden (ÇED) ve barajların lisanslandırılmasından sorumlu olan, Brezilya Çevre ve Yenilenebilir Doğal Kaynaklar Enstitüsü'ne (IBAMA) müdahale edilmiştir. Böylece adı geçen barajların kurulum ruhsatları, ön koşul olarak kabul edilen birçok şart yerine getirilmeden verilmiştir (Fearnside, 2014: 256).

Tapajos Nehri'nin bir kolu olan Teles Pires üzerinde Brezilya'nın hidroelektrik genişleme projesinin bir parçası olarak inşa edilen Colider Barajı, havzadaki büyük barajlardan bir diğeridir. Proje, 850 bin nüfusa sahip bir şehrin elektrik tüketimini karşlamaya yetecek kadar (yani 300 MW'lik) bir kurulu güç kapasiteyle yüklenmiștir. Mato Grosso eyaletine bağlı Colider şehrinin 40 km GB'sinde yer alan bu barajın inşası, 2015 yılında tamamlanmış ve ardında 171,7 km²'lik alan kaplayan bir rezervuar meydana gelmiştir (URL 8). 
Bunlardan başka yine Brezilya'nın Büyümesini Hızlandırma Programı çerçevesinde, Amazon Havzası'nda çok sayıda baraj, ya yapılmakta ya da inşa edilmesi planlanmaktadır.

Nitekim sadece Tapajos ve kolları için planlanan 5’i büyük olmak üzere toplam 40 baraj projesi, hükümet ile küresel mühendislik ve enerji şirketleri tarafından, Brezilya'nın resesyona girmesi ve ülkede ciddi elektrik sıkıntısı yaşanmasına bir çözüm olarak gündeme getirilmiştir. Projeler Brezilya'nın; 2024 yılına kadar 25 GW kapasitesinde HES barajı kurmasını, bunun yanında inşa edilecek bir dizi barajla da su yolu oluşturup soya ve diğer ticari ürünlerin Atlas Okyanusu üzerinden Avrupa'ya ihraç edilmesini de kapsamaktadır (URL 9).

Yapılması planlanan barajlardan rezervuar alanı bakımından en büyügü̈, Brezilya'nın Tapajos Nehri üzerinde inşa etmek istediği Sao Luiz do Tapajos'tur. Nitekim Para eyaleti sınırları içinde kalacak bu barajın ardında oluşacak gölün, $729 \mathrm{~km}^{2 \prime}$ lik bir alan kaplayacağı öngörülmüștür. Ayrıca bu barajın kurulu HES kapasitesininse 8.040 MW olması planlanmıştır (URL 10).

Ancak planlanan bu devasa barajla ilgili birtakım sorunlar ortaya çıkmıştır. Nitekim Brezilya Anayasası'na göre Amazon Havzası'ndaki yerlilerin yaşam alanlarını etkileyecek çalışmalar yapmadan önce hükümetin, onlardan onay alması gerekmektedir. Fakat inşa etmeyi planladığı Sao Luiz do Tapajos için hükümet, Munduruku yerlilerinin onayını almamıştır. Arazilerinde yapılmak istenen baraja yerlilerin karşı çıkması üzerine hükümet, silahlı güç kullanımına izin veren bir kararname çıkararak, barajı protesto etmek amacıyla toplanan göstericileri dağıtmak ve inşaat sorumlularını yerlilerin barikat kurduğu bölgeye sokmak istemiştir. Bu amaçla da 2013 yılının nisan ayında protestocuların üzerine bir ordu göndermiştir. Bunun üzerine hukukçular, insan hakları grupları ve çevreci örgütler, hükümeti kınayarak kaba kuvvete başvurmanın kanlı sonuçlara yol açabileceği konusunda endişelerini dile getirmişlerdir (URL 11).

Tapajos Havzası'nda yaşayan Munduruku ve diğer üç yerli halk grubunun liderleri yayınladıkları ortak bir manifestoda, arazilerinde yapılmak istenen baraja karşı çıkmalarına gerekçe olarak; söz konusu barajın yasal olmamasını, büyük bir yolsuzluk skandalına karışan hükümetin acele hazırlanan planlarla baraj inşa etmek istemesini, bunu yaparken de doğaya ve insanların yaşam alanına verilecek tahribatı görmezden gelmesini göstermişlerdir (URL 9).

Gerçekten de Sao Luiz do Tapajos Barajı'nın ÇED Raporu, birçok ciddi sosyoekonomik etkiyi görmezden gelmiş ve bir kısmını ise en aza indirgemiştir. Bu durum rasyonel karar vermekten ziyade, çevresel ve sosyal etkiler ne kadar ciddi olursa olsun, raporun üst makamların istediği şekilde ve finansal çekicilik göz önünde bulundurularak hazırlandığını göstermektedir. Karar verme ve lisanslama süreci; şirketlerin, politikacıların ve bürokratların karşılıklı etkileşimlerinin parasal ve parasal olmayan maliyetlerden bağımsız olarak ilerlemesi gereken bir sacayağıdır. ÇED de dâhil olmak üzere ülkede, karar alma ve lisanslama süreçlerinde herhangi bir projeyi engelleyen yasal veya anayasal kanunlar vardır. Fakat bu kanunlar, Brezilya Ulusal Kongresi'nde çevresel uyarıları pek dikkate almayan ve büyük toprak sahiplerinin çıkarları için çalışan "kırsalcı blok" tarafından değiştirilmek istenmektedir (Fearnside, 2015: 391).

Neticede iki taraf arasında yapılan mücadeleyi, barajın yapımına karşı çıkanlar kazanmıştır. Bunda 1988 Anayasası'nın, yerli halkların kendi topraklarından zorla çıkarılmasını yasaklaması etkili olmuştur. Ayrıca barajın önünde yasal engeller bulunduğunun bilinmesine rağmen hükümetin yapmak istediği Sao Luiz do Tapajos, sadece yerli bölgesini sular altında bırakmakla kalmayacak, aynı zamanda düzinelerce nehir topluluğunu da olumsuz bir şekilde etkileyerek geri dönüşü olmayan büyük çevresel yıkımlara sebep olacaktı. Bütün bunları dikkate alan Para Eyaleti Kamu Bakanlığı, söz konusu barajın lisansının iptal edilmesi gerektiğini IBAMA'ya bildirmiştir. Bunun üzerine 2016 yılında barajın lisans işlemi, bu kurum tarafından askıya alınmıştır (URL 12). 
Brezilya'nın Tapajos Nehri üzerinde inşa etmeyi planladı̆̆ı büyük projelerden bir diğeri, Jatoba'dır. Nitekim Para eyaletinde yapılmak istenen bu barajın rezervuarının $646 \mathrm{~km}^{2}$ yüzey alanına sahip olması beklenmektedir. Ayrıca Jatoba'nın toplam hidroelektrik üretim kapasitesininse $3.568 \mathrm{MW}$ olması planlanmıştır. Ancak söz konusu baraj projesi de biyoçeșitlilik açısından çok yüksek öncelikli ve yüksek öncelikli koruma sahasında bulunan Itaituba Ulusal Ormanı'nda 27,53 $\mathrm{km}^{2}$ genişliğinde bir alanı sular altında bırakacak (URL 13) olması nedeniyle büyük riskler taşımaktadır.

Tapajos Nehri üzerinde inşa edilmesi planlanan bir diğer büyük baraj da Chacorao'dur. Nitekim yine Para eyaletinde yapılacak bu barajın $616 \mathrm{~km}^{2}$ lik bir rezervuara ve toplam HES kapasitesinin de 3.336 MW'ye sahip olması planlanmıștır (URL 14). Ayrıca koruma alanlarını ve $187 \mathrm{~km}^{2}$ 'lik Munduruku yerli toprağını sular altında bırakacak olan bu baraja ilave edilecek kilit sistemiyle, mavnaların geçişi de mümkün olacaktır. Böylece daha önce de belirtildiği üzere Tapajos Nehri ve onun kolları olan Juruena ve Teles Pires üzerinden Mato Grosso eyaletinde yetiştirilen soya fasulyeleri, Amazon Nehri üzerindeki limanlara nakledilebilecektir. Ancak ülkenin anayasa ve yasalarındaki korumalar ile uluslararası sözleșmelerdeki kısıtlamalar gerekçe gösterilerek, Chacorao Barajı da askıya alınmıştır. Fakat yukarıda da değinildiği üzere siyasilerin bir kısmı, askıya almaya izin veren bu kanunları değiştirmek istemektedir (Fearnside, 2015: 426).

Amazon Havzası'ndaki barajlardan kurulu güç kapasitesi bakımından en büyüğü, Xingu Nehri üzerinde inşa edilen, Belo Monte'dir. Yine Para eyaletinde, Xingu Nehri'nin kuzey yarısında, Brezilya'nın enerji ihtiyacını karşılamak amacıyla inşa edilen bu barajın HES kapasitesi, 11.233 MW'dir (URL 15). Buna göre kurulu güç kapasitesi açısından Belo Monte, Çin'deki Three Gorges ile Xiluodu ve Brezilya-Paraguay sınırındaki Itaipu'dan sonra, dünyada dördüncüdür. Ayrıca bu barajın $500 \mathrm{~km}^{2}$ 'lik bir alanı sular altında bırakması da beklenmektedir (URL 11).

Lakin bu devasa barajın olumsuz etkileri daha inşa sürecindeyken bile ortaya çıkmıştır. Nitekim inşa sürecinde; 16 milyon tondan fazla balık ölmüș, kaplumbağa üreme alanları yok olmuş (URL 16), binlerce dönüm yağmur ormanı ve pek çok ada sular altında kalmıştır. Bunlara bağlı olarak da ribeirinhos olarak adlandırılan nehir kenarında yaşayan binlerce yerli, arazilerini ve geleneksel balıkçılık gibi geçim koşullarını kaybetmiştir. Ancak hükümet ve barajı inşa eden konsorsiyum, verilen zararları ne kabul ne de telafi etmiştir. Dahası hükümetin, yapılan çalışmaların Brezilya'nın menfaatine olduğu yönünde demeçler vererek, barajın inşasına karşı çıkan göstericilerin üzerine sert bir şekilde gittiği de olmuştur (URL 17).

Xingu Nehri'nin akışını \% 80 oranında kontrol altına alacak şekilde tasarlanan Belo Monte, Brezilya'daki yağmur ormanlarının önemli bir kısmına zarar vermenin yanında kırsalda ve şehirlerde yaşayan yaklaşık 40.000 kişiyi de yerinden etmiştir (URL 18). Dahası Belo Monte'nin; yerli topraklarının önemli bir kısmını sular altında bırakmak, tropik yağmur ormanlarını yok etmek ve sera gazı yaymak da dâhil olmak üzere çok ciddi sonuçları olmaya başlamıştır (Fearnside, 2006: 13). Buna karşın baraj inşaatı nedeniyle hem yaşam alanları ve hem de kültürleri tehdit altında olan yerli bölgesinin korunmasıyla ilgili şartlar, hükümet tarafından da yerine getirilmemiştir (URL 19).

Tüm bu olumsuzluklara, yapılan protestolara ve uluslararası örgütlerden gelen tepkilere rağmen Brezilya hükümeti, Belo Monte Projesi'ni 2019 yılının kasım ayında tamamlamıştır. Bunda politikacıların da dâhil olduğu bir yolsuzluk ve kara para aklama skandalının etkili olduğu, yapılan bir soruşturmayla ortaya çıkarılmıştır. Nitekim Belo Monte'yi yüklenen üç şirketin iktidardaki koalisyon partilerine; 2010, 2012 ve 2014 seçim kampanyalarında 41,4 milyon Amerikan Doları (USD) bağışta bulunduğu tespit edilmiştir. Ayrıca bu soruşturmayla, daha onlarca projeden ülkedeki siyasi partilere fon sağlandığı da saptanmıştır. Fakat buna karşın iktidar, yapılan bağışların yasalara uygun olduğunu iddia etmiştir. Ancak koruma uzmanları ve insan hakları savunucularına göre bu soruşturma, dünyanın biyolojik çeşitlilik açısından en zengin 
bölgelerinden birine ve yerli halkların da geçim kaynaklarına zarar vereceği bilinmesine rağmen söz konusu projenin neden durdurulmadığını izaha kavuşturmuştur (URL 20).

Brezilya'da yapılmak istenen HES projeleriyle ilgili burada dile getirilmesi gereken bir başka husus da, ülkede barajlara karşı mücadele ederken öldürülen insanlardır. Nitekim Global Witness'in hazırladığı rapora göre 2015 yılında dünya çapında barajlara karşı örgütlü bir mücadele sürdürürken öldürülen 185 yerli veya çevreciden 50'si Brezilya'ya aittir. Buna göre sözü edilen ülke, belirtilen yılda çevre aktivisti cinayetlerinde dünyada birinci sırada yer almıștır (Global Witness, 2016: 9).

Havza ülkelerinden Peru da önümüzdeki on yıllarda Amazon'un kendi sınırları içinde kalan kısmında 70'den fazla baraj inşa etmeyi planlamaktadır (Aguirre 2014: 7). Bu barajların kimisi Peru'nun kendi imkânlarıyla, kimisi de Amerika Birleşik Devletleri (ABD) ve Brezilya gibi ülkelere imtiyazlar verilmek suretiyle gerçekleştirilmek istenmektedir.

Nitekim bu amaçla Peru hükümeti, ABD ile 1 Şubat 2009 tarihinde yürürlüğe giren Serbest Ticaret Antlaşması imzalamıștır. Buna göre Peru'da; güvenli ve öngörülebilir bir yasal çerçeve oluşturularak ABD'li şirketlerin yapacağı her türlü yatırım koruma altına alınmıştır. Hatta bu antlaşmayla ABD'li yatırımcılar, neredeyse Peru vatandaşlarıyla eşit şartlar altında şirket kurma, satın alma ve işletme hakkına da sahip olmuștur (URL 21).

Yine bu antlaşmayla hükümet, Amazon'un Peru'da kalan kısmını; enerji üretme, petrol arama, endüstriyel tarım, madencilik ve petrol çıkarma gibi faaliyetler açısından ABD'li firmalara açmıştır. Bunu sağlamak için de şirketlerin, yerli topraklarını satın almasını kolaylaştıran 9 tane yasa çıkarmıştır. Bunun üzerine yerliler, yüzyıllardır üzerinde oturdukları ve ekip biçtikleri topraklarla ilgili devlet politikaları olușturulurken hükümetin kendilerini dikkate almadığını, Uluslararası Çalışma Örgütü'nün yerlileri ilgilendiren konvansiyonuna göre böyle bir karar alınırken kendilerine danışılması gerektiğini ileri sürerek 2009 yılının nisan ayında sokağa dökülmüştür (URL 22).

Yağmur ormanlarının yabancı şirketlere kiralanmasına imkân tanıyan Güney Amerika Serbest Ticaret Antlaşması Yasası'na karşı ülkenin kuzeyindeki Utcubamba eyaletinin Cruz del Diablo (Şeytan Geçidi) bölgesinde, başlayan protestoların önüne geçebilmek için Peru hükümeti, 9 Mayıs 2009 tarihinde 4 eyalette OHAL ilan etmiştir. 5 Haziran 2009 tarihinde polisin Bagua Grande kasabası yakınında; anayol, su ve petrol hatlarını kapatma eyleminde bulunan 65 yerli gruba saldırıp helikopterden ateş açması üzerine çatışma çıkmıștır. 30 yerli ve 10 'dan fazla polisin hayatını kaybettiği olaylarda çok sayıda kişi de yaralanmıştır. Nüfusu 600.000'i bulan 1.350 yerli topluluk adına konuşan AIDESEP başkanı Alberto Pizango, silahsız göstericilere saldırı emrini verdiği için yaşananlardan iktidarı sorumlu tutmuş ve hükümetten, $250.000 \mathrm{~km}^{2}$ 'lik ata toprağını işgalden ve kendilerine de ikinci sınıf vatandaş muamelesi yapmaktan vazgeçmesini istemiştir (URL 23).

İnsan hakları savunucuları tarafından yaşanan olaylarda, gerçekte yüzlerce kişinin öldüğü fakat cesetlerin polis tarafından gizlendiği için onlara ulaşılamadı̆̆g, dile getirilmiştir. Olayların meydana geldiği Bagua Grande kasabası yerlileri, iktidarın insanlığa karşı suç işlediğini söylerken hükümetse, olaylarda asıl kurbanın polis olduğunu iddia etmiştir (URL 24).

Yaşanan bu gelişmeler, gerek ülke içinde ve gerekse ülke dışında büyük yankı uyandırınca yerlilerin ve çevrecilerin karşı çıktığı yasalar yürürlükten kaldırılmış ve 2009'un temmuz ayında; başbakan, savunma, içişleri, adalet ve tarım bakanları görevden alınmıştır (URL 22). Böylece olayların yatışmasının ve taraflar arasında müzakere edilmesinin yolu açılmıştır. 
Fakat daha bu olaylar henüz yeterince soğumadan Peru hükümeti bu kez de 2010 yılının haziran ayında Brezilya ile bir enerji sözleşmesi imzalamıştır. 50 yıl geçerli olacak bu sözleşmeye göre Amazon'un Peru'da kalan kısmında çoğunluğu, Brezilya tarafından finanse edilecek 6.000 MW'den fazla enerji üretme kapasitesine sahip HES barajları inşa edilecek ve buradan elde edilecek enerjinin de büyük bir kısmı yine Brezilya'ya ihraç edilecektir (URL 25).

Bunu gerçekleştirmek için Peru hükümeti, 2011 yılında çıkardı̆̆ bir yasayla Maranon Nehri üzerinde Ulusal Enerji Devrimi başlattığını ilan etmiştir. Buna göre hükümet, ülkenin yüksek büyüme oranlarıyla kalkındığını varsayarak, Peru'nun potansiyel elektrik talebinin 2025 yılına kadar 12.000 MW'nin biraz üzerinde olacağını öngörmüştür. Ancak 2011 yasasına göre sadece Maranon Nehri'nin ana gövdesi üzerinde yapılması planlanan 20 barajın kurulu gücünün 12.400 MW'yi aşması, Peru'nun ihtiyacından fazla elektrik enerjisi üretmek istediğini göstermektedir (URL 26).

Antlaşma kapsamında planlanan projeler gerçekleştiği takdirde ortaya çıkacak zararların en büyüklerinden birisi de ormanlık alanların sular altında kalması sonucunda buraların ciddi oranda sera gazı emisyonuna sebep olacak olmasıdır (URL 25).

Dahası Maranon Nehri üzerinde inşa edilecek 20 barajla Peru hükümeti, And Dağları'ndaki maden sahalarının enerji ihtiyacını karşılamayı da hedeflemektedir. Bundan başka baraj projelerinin bazılarından, kurak kıyı bölgelerine kurulacak sulama sistemlerine su transfer edilmesi de planlanmaktadır. Ancak yapılmak istenen bu barajların 18'i, bulut ormanları ve ekvatoral mevsimsel kuru orman alanları gibi hassas ekosistemlerde yer almaktadır. Dahası nehirlerden büyük tarımsal işletmeler için su sağlanması, bu bölgedeki akarsular ve taşkın alanlarının ekolojisini de olumsuz bir şekilde etkileyecektir. Birçoğu kakao, mürgen, mısır, yer fıstığı ve manyok yetiştiren Awajun ve Wampis yerlileri, bu barajların topraklarını sular altında bırakmasından endişe etmektedir. Nitekim nehre ve orman kaynaklarına bağımlı olan bu yerlilerin bölgedeki avlanma ve tarımsal geçim kaynakları, söz konusu projelerden ciddi bir şekilde etkilenecektir. Ayrıca bu toplulukların verimsiz topraklara ya da işsizliğin fazla olduğu kalabalık kent merkezlerine yeniden yerleştirilmesi de sosyal bir takım sorunlara yol açacaktır (URL 4).

Peru hükümetinin Maranon Nehri'nde inşa etmeyi planladığı barajların en büyüklerinden birisi, Chadin II'dir. Bu barajla, ülkenin kuzeyindeki dağlık Cajamarca bölgesindeki altın ve bakır bulunan maden sahalarının ihtiyaç duyduğu enerjinin karşılanması amaçlanmaktadır. Maranon ilinde yapılması planlanan bu barajın, $32 \mathrm{~km}^{2}$ lik bir alanı suları altında bırakması ve 20 kasabayı da etkilemesi beklenmektedir. Barajın suları altında bırakacağı verimli vadide yaşayan yerliler; papaya, muz, portakal, limon, mango ve koka yaprağı yetiştirerek bunları Cajamarca eyaletine bağlı şehirlerde satmaktadır. Peru yasalarına göre devletin, olası etkiler hakkında bilgi verilmesi ve topluluklardan ÇED konusunda geribildirim alınması amacıyla proje geliştiricisi ve etkilenen topluluk arasında kamuya açık oturumlar düzenlemesini gerekmektedir. Fakat Chadin II konusunda bu yasa uygulanmadığı gibi polis, projeyi protesto eden yerlilerin üzerine agresif bir şekilde gitmiștir. Bunun üzerine sivil toplum örgütleri, Peru Devleti'nin yaygın olarak sergilediği bu saldırgan tutumu kınamıştır (Aguirre 2014: 7).

Nitekim Global Witness'in hazırladığı rapora göre sadece 2015 yılında dünya çapında barajlara karşı örgütlü bir mücadele sürdürürken öldürülen 185 kişiden 12'si Peru'ya aittir. Buna göre belirtilen yılda aktivist cinayetlerinde Peru; Brezilya, Filipinler ve Kolombiya'nın ardından dünyada dördüncü sırada yer almıştır (Global Witness, 2016: 9).

İnsanların yerinden olması, ekilebilir arazilerin kaybedilmesi, $120 \mathrm{~km}^{2}$ 'lik ormanın yok edilmesi, rezervuarın sebep olacağı sera emisyonu, biyoçeşitlilik kaybı ve sucul sistemin zarar görmesi gibi çevresel ve sosyal olumsuzluklara rağmen (Aguirre 2014: 7) baraja karşı çıkanlara devlet 
tarafından; sindirme, baskı ve zulüm uygulanarak Chadin II'nin tartışmalı ÇED raporu, 2014 yılında onaylanmıştır. Bundan başka yine Cajamarca bölgesindeki maden sahalarının enerji ihtiyacının karşılanması amacıyla Maranon Nehri üzerinde yapılması planlanan Rio Grande I ve II gibi barajların fizibilite çalışmaları için de imtiyazlar verilmiştir (URL 26).

International Rivers tarafından 2014 yılında hazırlanan bir çalışma, Maranon'un geleceğine ilişkin Peru planlarının havza açısından büyük bir tehlike arz ettiğini ortaya koymuştur. Nitekim Maranon üzerinde yapılması planlanan en az 20 barajın rezervuarı, nehrin ana gövdesinin \% 80 'ine tekabül eden yaklaşık $7.100 \mathrm{~km}^{2}$ 'lik bir araziyi sular altında bırakacaktır. Bu da şu andaki nehir ana yatağının, neredeyse tamamen boğulacağı anlamına gelmektedir. Yine bu barajlar, Maranon Nehri tarafından taşınan ve Amazon Havzası'nı destekleyen büyük miktardaki; tortuyu, minerali, besin maddesini ve balık göçlerini de bloke edecektir. Bu da bölgenin; eşsiz biyoçeşitliliği, hassas ekosistemi ve nehir tarafından sağlanan gıdalardan beslenen ve buradan gelir sağlayan yoksul topluluklar için büyük bir yıkım anlamına gelmektedir (URL 27).

Maranon için Peru'nun hazırladığı planlar, su ve tortu akışlarında çarpıcı değişikliklere yol açacaktır. Ayrıca bu projeler, biyolojik çeşitlilik açısından oldukça zengin olan yağmur ormanlarındaki pek çok endemik türün de yok olmasına ve henüz tam olarak kestirilemeyen ekolojik sonuçlara neden olacaktır (URL 26).

İşte bu gibi nedenlerle yerli toplulukların ve çevrecilerin muhalefetiyle karşılaşan sözleşme kapsamındaki; Pakitzapango, Tambo-40 ve Inambari barajları askıya alınmıştır. Dahası Peru Anayasası'na ve uluslararası hukuka göre, yerli halkların toprakları üzerinde yapılmak istenen projelerde onlara danışılması gerekmesine rağmen yerli halkların önceden bilgilendirilmediği ve onların temel haklarını tehdit ettiği gerekçesiyle Brezilya'yla imzalanan sözleşmenin askıya alınması istemiyle de Lima'daki Yüksek Adalet Divanı'nda dava açılmıştır (URL 25).

\section{MATERYAL VE YÖNTEM}

Bu çalışmanın amacı, drenaj alanı ve deşarj açısından dünyanın en büyük akarsuyu olan Amazon Nehri Havzası'ndaki sürdürülebilir sosyoekonomik kalkınmayı tehdit eden unsurların neler olduğunu tespit ederek bunlara ilişkin çözüm önerileri getirmektir.

Araştırmaya önce söz konusu akarsu havzasının konumunu ve sınırlarını gösteren bir haritanın, Coğrafi Bilgi Sistemi (CBS) yazılımı olan ArcMap10.1 kullanılarak, çizilmesiyle başlanmıştır (Şekil 1). Bundan sonra da yine aynı yazılımla Amazon Nehri Havzası ve bu havzanın çevresini gösteren bir fiziki harita hazırlanmıştır (Şekil 2). Söz konusu havzadaki akarsulara ilişkin uzunluk bilgileri, aynı zamanda çalışmaya görsellik de katan, bu haritalara dayalı olarak verilmiştir.

Ardından literatür taraması yapılarak konuyla ilgili hazırlanan; rapor, makale, kitap, dergi ve diğer kaynaklar temin edilmiştir. Bunlardan Amazon Havzası'nda; hangi ülkenin ne kadar toprağı bulunduğu, nehrin kolları, nehrin kolları üzerinde inşa edilen ve edilmek istenen önemli su yapıları, bu yapıların ve beșeri müdahalelerin havzanın ekosistemi üzerindeki etkilerinin neler olduğu ve risklerinin neler olacağı gibi birtakım bilgilere ulaşılmıştır.

Bu bilgilerden en dikkat çekici olanıysa, havzanın akarsu sistemi açısından hayati öneme sahip olmasının yanında dünyanın akciğerleri olarak da kabul edilen, Amazon Yağmur Ormanları'na yıldan yıla verilen büyük zarardır. Bu zararın havzadaki boyutlarını daha net bir şekilde ortaya koyabilmek için de uzaktan algılamaya dayalı olarak elde edilen ve Normalize Edilmiş Fark Bitki Örtüsü İndeksi (NDVI / Normalized Difference Vegetation Index) olarak adlandırılan analiz yöntemi gerçekleştirilmiştir. Bu yöntemle elde edilen sonuçlar da, yine ArcMap10.1 yazılımı kullanılarak, üçüncü bir haritayla (Şekil 3) görselleştirilmiştir. 
Daha sonra buraya kadar sözü edilen tüm veriler gözden geçirilerek nehir havzasında sürdürülebilir sosyoekonomik kalkınmayı tehdit eden unsurların neler olduğu tespit edilmiştir. Çalışmanın nihayetinde de bu sorunların çözümüne ilişkin öneriler, sentez yöntemiyle ortaya konulmuştur.

\section{BULGULAR}

Amazon Nehri Havzası'nda sürdürülebilir sosyoekonomik kalkınmayı tehdit eden unsurların neler olduğunu ortaya koymak amacıyla hazırlanan bu çalışmadan elde edilen bulgular şunlardır:

Havzada sürdürülebilir sosyoekonomik kalkınmayı tehdit eden unsurlardan ilki, adeta doğayla savaşırcasına Amazon Nehir Sistemi'nde HES barajları yapılmasıdır. Nitekim bașta Brezilya ve sonrasında da Peru'nun başını çektiği bu tür barajlar, gerek doğaya ve gerekse insanlara büyük zararlar vermektedir. Baraj yapımından en fazla etkilenecekler yerliler olduğu için ilk tepki de onlardan gelmekte ve bunların protestolarına çevreci gruplar da dâhil olmaktadır.

Çoğu zaman yapılmak istenen HES barajları havza ülkelerinin yasalarıyla da çelişmesine rağmen hükümetler, protestoculara karşı zaman zaman güç de kullanmak suretiyle, projelerini adım adım gerçekleştirmeye devam etmektedir. Fakat iktidardakiler, tepkisi zaman içinde ve sessiz bir şekilde meydana geldiği için, doğayı ya yok saymakta ya da pek fazla dikkate almamaktadır. Havzada bu şekilde yapılan barajlara karşı doğanın verdiği tepkilerin bazıları şunlardır:

Geniş orman alanlarını sular altında bıraktı̆̆ı için bu barajlar; muazzam metan emisyonlarına sebep olmaktadır. Buna göre Amazon Nehir Sistemi'ni bekleyen en büyük tehlike, iklim değiş̧ikliğidir. Nitekim giderek artan bir oranda havzada yağış modellerinin değişime uğraması da bunu doğrulamaktadır. Aynı zamanda HES'lerdeki enerji verimliliğini de azaltan bu durum nedeniyle havzada büyük yatırımlar yapılarak inşa edilen barajlar, uzun vadede büyük bir risk altındadır (Tollefson, 2011: 160).

Amazon'un en büyük kolu olan ve onun toplam tortu miktarının neredeyse yarısını tek başına karşılayan Madeira üzerinde kurulan Santo Antonio ve Jirau barajları, bu nehirden Amazon'a dâhil olan sedimanın \% 20 oranında azalmasına sebep olmuştur. Meydana gelecek sellerde bu oranın daha da artması beklenmektedir. Barajların ardında sedimanların depolanmasının etkileri sadece yerel değil, aynı zamanda bölgesel olarak da hissedilecektir. Çünkü nehirlerin taşıdığı tortu; yaban hayatı ve bölgesel gıda kaynaklarını sürdürme açısından da önemlidir. Ayrıca havzadaki nehirler, her yıl Amazon'a ve dolayısıyla Atlantik'e milyonlarca ton tortu salmaktadır. Okyanus akıntılarıyla bu tortular; Brezilya'nın KD kıyılarına, Surinam'a ve Fransız Guyanası'na kadar dağılmaktadır. Güney Amerika'nın en büyük mangrov ormanlarının bulunduğu bu alanlara sediman akışının engellenmesinden, tüm deniz sistemi zarar görecektir. Dahası Amazon'un Atlantik'e saldığı tortu, Karayipler ve Meksika Körfezi boyunca tropikal fırtınaların yollarını da etkilemektedir. Dolayısıyla ekosistemin bu önemli bileşeninin ortadan kaldırılmasının bedeli de oldukça ağır olacaktır (URL 28).

2009-2012 yılları arasında yapılan bir araştırmayla, Ucayali Havzası'nda belirgin bir tortu birikimi tespit etmiştir. Bu akarsuyun havza alanından ihraç edilen ağır yük, okyanusa bırakılan Amazon yükünün yaklaşık \% 36'sına tekabül etmektedir. Neojen zamanında And Dağları'nın yükselmesine bağlı olarak çöküntülerin yaklaşık \% 40'ı Ucayali retro-foreland havza sisteminde sıkışmıştır. Bu da Yukarı Ucayali Havzası'ndaki aşındırma oranlarının fazla olmasına neden olmaktadır (Santini vd., 2014: 320). Dolayısıyla böyle yerlere inşa edilen HES barajlarının rezervuarları kısa süre içinde dolacağından, yapımı için çevreye ve insanlara verilen zarara oranla buralardan elde edilecek ekonomik getiri de oldukça az olacaktır. 
Baraj yapımına karşı doğanın verdiği ve gelecekte daha da artması beklenen bu tepkilere rağmen Brezilyalı yetkililer; Çin ya da Hindistan gibi gelişmekte olan ülkelere göre Brezilya'nın fosil yakıtlara bağımlı olmadığını, HES'lerin ülkenin enerji ihtiyacını karşılamada önemli bir yeri olduğunu ve bu projelerle Brezilya'nın Paris İklim Değişikliği Antlaşması'ndaki taahhütlerini yerine getirdiğini iddia etmektedir. Dahası Brezilya Kongresi'nde mevcut çevre yasalarını zayıflatacak kanunlar da bir yandan tartışılmaya devam etmektedir. Eğer bu kanunlar geçerse, tartışmalı kalkınma projeleri yapılabilecek ve çevresel kaygılar nedeniyle reddedilenler veya rafa kaldırılanlar da tekrar işleme konulabilecektir (URL 17).

Bu gibi durumların önüne geçebilmek için faaliyet gösteren sivil toplum örgütleri de vardır. Nitekim International Rivers, Amazon nehirleri ile doğasının korunması için çalışmalar yapmakta ve yaşamı tehdit edilen toplulukların haklarını etkili bir şekilde savunmaktadır (URL 4). Bundan başka Amazon Watch, Greenpeace, Global Witness ve Mighty Earth de aynı amaçlar doğrultusunda mücadele veren diğer sivil toplum örgütleridir.

Havzada sürdürülebilir sosyoekonomik kalkınmayı tehdit eden unsurlardan ikincisiyse, dünyanın akciğerleri olarak kabul edilen ve Amazon'un akarsu sistemi açısından hayati öneme sahip olan yağmur ormanlarının; baraj yapımı için kesilmesi veya yapılan barajların rezervuarında biriken suların altında kalması, tarım alanı açmak amacıyla yangınlar çıkarılması, yasal veya kaçak kesilmesi, maden sahası açılması ve yeni yollar inşa edilmesi gibi sebeplerle gittikçe azalmasıdır (URL 29).

Sayılan olumsuzluklardan baraj inşa etmek suretiyle ormanlık alanlara verilen zararlara yukarıda değinilmişti. Bundan sonra Amazon Yağmur Ormanları'na en fazla zarar, tarım alanı açmak suretiyle verilmektedir. Gerçekten Mighty Earth adlı kuruluş, fast food devleri ve onların (Cargill ve Bunge gibi) taşeronlarının, başta soya olmak üzere, bitkisel yağ ve tahıl üretilecek tarlalara yer açmak amacıyla Brezilya ve Bolivya'daki tropik ormanları yakarak yok ettiğini ortaya çıkarmıştır. Burada özellikle fast food devlerinden Burger King'in adı ön plana çıkmaktadır. Nitekim söz konusu araştırmaya göre, 2011 ilâ 2015 yılları arasında sadece bu şirket için 7.000 $\mathrm{km}^{2 \prime}$ lik orman arazisi yakılmıştır. Belirtilen amaçlar doğrultusunda Brezilya'da; 2015 yılında $15.000 \mathrm{~km}^{2}, 2016$ yılındaysa $20.000 \mathrm{~km}^{2}$ orman arazisi yok edilmiştir. Aynı maksatlarla havza ülkelerinden Bolivya'da yakılan orman arazisiyse, $8.650 \mathrm{~km}^{2}$ 'dir. Et endüstrisini daha kârlı hale getirmek için yapılan bu tahribat esnasında; jaguar, karıncayiyen ve tembel hayvan başta olmak üzere on binlerce yaban hayvanının da yanarak öldügü sanılmaktadır (URL 30).

Bu yangınların sebep olduğu kirlilik yüzünden, her yıl Amazon'da yüzlerce erken ölüm olayı meydana gelmektedir. Ayrıca buradaki ormansızlaşma, küresel çapta yaşanan iklim değişikliğine de olumsuz bir şekilde yansımaktadır. Nitekim 2016 yılında Brezilya'nın sera gazı emisyonlarının \% 51'i ülkedeki arazi kullanımında meydana gelen değișikliklerden kaynaklanmıștır. Ve bunun sonucunda Brezilya, dünyayı en çok kirleten yedinci ülke konumuna gelmiştir. Yapılan ölçümlere göre son yıllarda orman kaybı nedeniyle Xingu Havzası'ndaki sıcaklıkların $0,5{ }^{\circ} \mathrm{C}$ arttığı tespit edilmiştir. $\mathrm{Bu}$ da kuraklığa sebep olarak havzadaki tarımsal üretimi olumsuz bir șekilde etkilemektedir (Amazon Institute for Environmental Research, 2017: 4).

Yine Amazon'un başlıca kollarından birisi olan Purus üzerine yapılan bir araştırma, bu nehrin havzasındaki ormanlık alanların \% 5,17'sinin yok edildiğini ortaya koymuştur. Söz konusu nehir havzasındaki ormanlar, Brezilya'da yüksek koruma statüsünde bulunmasına rağmen son yıllarda; başta soya fasulyesi olmak üzere çeşitli tarım ürünleri yetiştirmek ve et endüstrisi için sığır çiftlikleri açmak gibi nedenlerle sürekli tahribata uğramaktadır. $\mathrm{Bu}$ da nehrin, pH seviyesinde düşüşe ve sıcaklığında artışa neden olmaktadır. Benzer durumlar, ormansızlaşma nedeniyle Amazon'un diğer kollarında da gözlenmektedir (Ríos-Villamizar, vd., 2017: 81). 
Her ne kadar yoğun tarım kadar olmasa da madencilik de havzada orman tahribatına neden olan bir diğer faaliyettir. Nitekim bakır, kalay, nikel, boksit, manganez, demir cevheri ve altın gibi mineral varlıklar açısından Amazon'un büyük bir potansiyele sahip olduğu düşünülmektedir. Kalkınma hızlarını artırabilmek için havza ülkeleri, büyük ölçekli maden projelerine vergi teşvikleri sağlamaktadır. Ancak bu faaliyetler sadece orman alanlarını tahrip etmekle kalmamakta, aynı zamanda gerek madencilik sahası çevresinde ve gerekse ekstraksiyon işlemlerinin akış aşağısında, doğaya birtakım zararlar da vermektedir (URL 31).

Altın başta olmak üzere havzadaki madencilik faaliyetleri, küresel ekonomiyle yakından ilişkilidir. Nitekim 2008 yılında ortaya çıkan global ekonomik kriz sonrasında altın fiyatlarının yükselmesine bağlı olarak Batı Amazon'da bu madencilik, 2008-2012 yılları arasında belirgin bir şekilde artmıştır. Bu faaliyetin en hızlı geliştiği yerlerden biri de Peru'nun Madre de Dios Bölgesi'dir. Bu bölgedeki yağmur ormanı, biyoçeşitlilik açısından dünyadaki en zengin yerlerden biridir ve aynı zamanda da önemli bir karbon deposudur. Söz konusu bölgede üç büyük maden şirketi dışında binlerce de küçük ölçekli ve çoğunluğu yasadışı faaliyet gösteren işletme bulunmaktadır. Hem küçük hem de sık sık yer değiştirdikleri için geleneksel uydu görüntüleriyle bunların tespiti oldukça güçtür. Bu nedenle yüksek çözünürlüklü uydu görüntüleri kullanılarak yapılan bir araştırma, 1999 yılında $100 \mathrm{~km}^{2}$ olan altın madenciliği alanlarının 2012 yılında 500 $\mathrm{km}^{2}$ 'ye çıktığını ve bunun da yarıdan fazlasını küçük işletmelerin oluşturduğunu ortaya koymuştur (Asnera vd., 2013: 18456-18457).

2017 yılında Brezilya hükümeti, ülkedeki ekonomik durumun kötülüğünü gerekçe göstererek $47.000 \mathrm{~km}^{2}$ lik bir alanda altın, demir, bakır ve manganez çıkarılmasına izin veren bir kararname çıkarmıştır. Fakat dünyanın akciğerleri olarak kabul edilen bir bölgeyi madenciliğe açmanın; ormanlar, bölgedeki biyoçeşitlilik ve yerel halk için büyük bir yıkıma neden olacağı yönünde uluslararası ve ülke kamuoyundan tepkiler gelmiştir. Bunun üzerine hükümet, oluşan iç ve diş baskılar nedeniyle önce kararnameyi askıya almış ve ardından da yürürlükten kaldırmıștır (URL 32).

Ormansızlaşmadaki artışın bir diğer nedeni de bu yasadışı faaliyeti işlemekle suçlanan toprak sahiplerine, 2012 yılında olduğu gibi, çıkarılan aflardır (URL 33). Tüm bunlar neticesinde Amazon Nehri Havzası'ndaki ormanların kapladığı alan, sürekli azalmaktadır.

Havzadaki yağmur ormanlarının uğradığı bu tahribatın boyutunu, uzaktan algılama yoluyla da ortaya koymak mümkündür. Nitekim bu maksatla, NASA'nın Oak Ridge Ulusal Laboratuvarı Aktif Arşiv Merkezi'nden elde edilen raster veriler (URL 34) kullanılmak suretiyle, 2002-2020 yılları arasında Amazon yağmur ormanlarındaki değişimi karşılaştırmalı olarak gösteren bir harita çifti (Şekil 3) hazırlanmıştır. Ardından da sözü edilen haritalardaki raster verilerin vektörel verilere dönüştürülüp bunların alanlarının hesaplanmasıyla da Tablo 2 oluşturulmuştur.

İlgili tabloda da görüleceği üzere 2002 yılında Amazon Nehri Havzası'ndaki ormanlık alanın yüzölçümü $4.828 .220,1 \mathrm{~km}^{2}$ 'den 2020 yllında $4.430 .505 \mathrm{~km}^{2}$ 'ye kadar gerilemiştir. 397.715 $\mathrm{km}^{2}$ 'lik bu tahribat neticesinde havzadaki yağmur ormanlarının kapladığı alan \% 70,3'ten \% 64,5'e düşmüştür.

Havzada sürdürülebilir sosyoekonomik kalkınmayı tehdit eden unsurlardan üçüncüsüyse, kirliliktir. Bu problemeyse yukarıda da değinildiği üzere daha çok madencilik faaliyetleri sebep olmaktadır. Bundan başka akarsu sistemi üzerinde; şehirlerden bırakılan atıkların, sanayi alanlarından salınan kirleticilerin ve tarım alanlarından dâhil olan kimyasalların da olumsuz etkisi söz konusudur.

Nitekim Uluslararası Örgütlü Suçlarla Mücadele Girişimi'ne göre 2006 ile 2016 yılları arasında Amazon Havzası'ndan yasadışı olarak 68 ton altın çıkarılmıştır. Bu yasadışı faaliyetler yüzünden 
her yıl Amazon nehirlerine 30 tondan fazla ölümcül cıva karışmaktadır. Bu da sadece balıkları zehirlemekle kalmayıp aynı zamanda bu nehirlerin yüzlerce km aşağısındaki insanlarda bile beyin hasarı görülmesine sebep olmaktadır (URL 35).

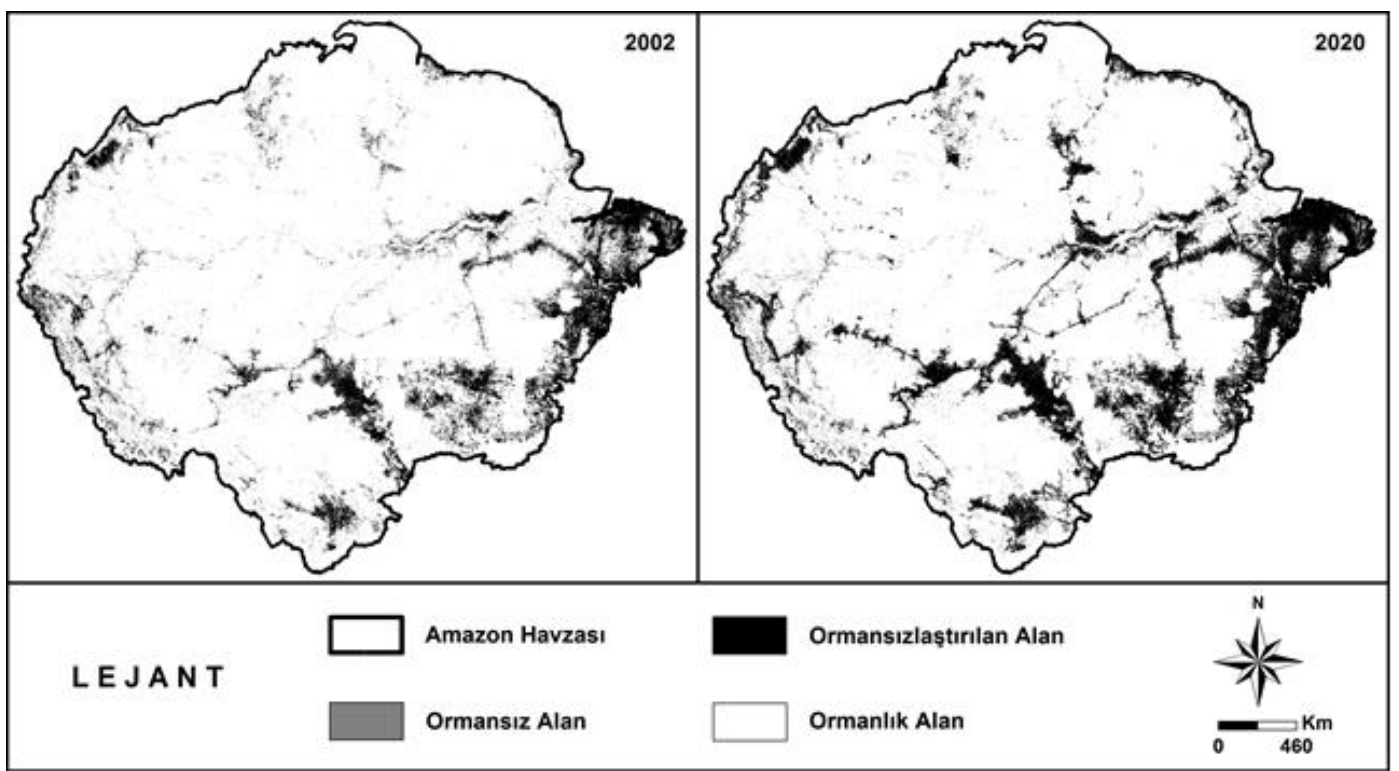

Şekil 3. 2002-2020 Yılları Arasında Amazon Yağmur Ormanları'na Verilen Tahribatı Gösteren Karşılaştırmalı Harita

Tablo 2. 2002-2020 Yılları Arasında Amazon Nehri Havzası'ndaki Yağmur Ormanları Sahasında Meydana Gelen Değişim

\begin{tabular}{|c|c|c|c|c|c|}
\hline \multirow{2}{*}{\multicolumn{2}{|c|}{ Amazon Nehri Havzası'nın }} & \multicolumn{2}{|l|}{2002} & \multicolumn{2}{|l|}{2020} \\
\hline & & \multirow{2}{*}{ 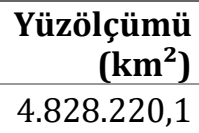 } & \multirow{2}{*}{$\begin{array}{l}\text { \%'si } \\
70,3\end{array}$} & \multirow{2}{*}{ 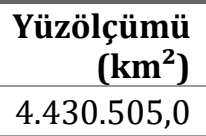 } & \multirow{2}{*}{$\begin{array}{l}\text { \%'si } \\
64,5\end{array}$} \\
\hline \multirow{3}{*}{$\begin{array}{l}\text { Yağmur } \\
\text { Ormanları } \\
\text { Dâhilindeki }\end{array}$} & Ormanlık Alan & & & & \\
\hline & $\begin{array}{l}\text { Ormansızlaştırılmış } \\
\text { Alan }\end{array}$ & $631.261,1$ & 9,2 & 1.028.976,2 & 15,0 \\
\hline & $\begin{array}{l}\text { Orman Örtüsü } \\
\text { Bulunmayan Alan }\end{array}$ & $866.180,9$ & 12,6 & $866.180,9$ & 12,6 \\
\hline \multicolumn{2}{|c|}{ Yağmur Ormanları Haricindeki Alanlar } & $543.337,9$ & 7,9 & $543.337,9$ & 7,9 \\
\hline \multicolumn{2}{|l|}{ Toplam } & $6.869 .000,0$ & 100,0 & $6.869 .000,0$ & 100,0 \\
\hline
\end{tabular}

Kaynak: Şekil 3'teki raster veriler üzerinde yapılan NDVI analizi sonucunda hesaplanmıștır.

Gerçekten de altının iyileștirilmesinde yaygın bir şekilde kullanılan cıva, tüm kimyasal formları toksik sonuçlara yol açtığı için çevre ve insanlar için oldukça tehlikeli bir metaldir. Havzada altın madenciliği nedeniyle bu ağır metalin görüldüğü yerlerin bașında, Amazon'un en büyük kolu olan Madeira Nehri ve çevresi gelmektedir. Nitekim bu nehir çevresindeki 10 farklı bölgeden alınan toprak numunelerine göre en büyük clva konsantrasyonun, Rondonia eyaletine bağlı Porto Velho şehri ile Amazonas eyaletine bağlı Humaita şehirleri arasında olduğu tespit edilmiştir (Linhares vd., 2005: 377-378).

Yine Madeira Havzası'nda; nehir suyunda ve tortullarda, orman topraklarında, balıklarda, havada ve insan kıllarında; cıva düzeyleri incelenmiştir. Buna göre özellikle büyük altın madenciliği alanlarına yakın akan nehirlerde bu metal seviyesinin yüksek olduğu tespit edilmiştir. Gerçekten de sözü edilen bölgelerdeki balıklarda cıva seviyeleri 2,7 ppm'e kadar çıkmaktadır. Atmosferik 
cıva seviyeleri düşük olmakla birlikte, bu değerler cıva-altın yeniden üretme kompleksi yakınlarında yüksek değerlere $\left(3,2 \mathrm{mg} / \mathrm{m}^{3}\right)$ erişebilmektedir. Ayrıca yerel halkın saçında 26,7 ppm değerlerine kadar cıva tespit edilmesi, insanların oldukça yüksek seviyede bu elemente maruz kaldığını göstermektedir (Pfeiffer vd., 1991: 239).

Akarsuyun kirlenmesindeki bir diğer husus da Brezilya'nın kuzeyindeki belli başlı kentlerin Amazon Nehri ve kolları üzerinde bulunmasıdır (Rodrigues ve Maciel, 2017: 459). Nitekim bunlardan birisi de, hızla büyümesi nedeniyle eski su yollarının birçoğu ya yok olan ya da kirlenen, Manaus şehridir. Bu şehrin kirli sularının kenar boşluklarında palafita olarak adlandırılan küçük ahşap evlerde, yüzlerce fakir aile yaşamakta ve bunlar bütün çöpünü akarsuya atmaktadır. Bunun yanında kanalizasyon boşaltımı nedeniyle belediye ile şehrin yakın çevresindeki ormanlara ve su kaynaklarına zarar veren büyük işletmeler de nehrin kirlenmesinden sorumludur. Ocak ilâ mayıs ayları arasındaki yağışlı dönemde meydana gelen sellerde Negro ve kolları ile şehrin su yollarında çöpler daha da birikerek tıkanıklıklara sebep olmaktadır. Bunu önlemek için Manaus'un su kanallarından her ay ortalama 900 tondan fazla çöp çıkarılmaktadır. Ancak nehre atık bırakmaya devam edildiğinden, problem bir türlü çözülememektedir. Bunların bir sonucu olarak nehir kenarında yaşayanlar sudan bulaşan; hepatit A, hepatit E, ishal, amebiyaz, giardiyaz ve leptospirosis gibi hastalıklara maruz kalmaktadır (URL 36).

Ayrıca sadece 2016 yılında Manaus şehrinde tarama usulüyle yapılan çöp toplama işlemlerinin yıllık maliyeti, 3.441.570 USD olmuştur. Dahası çöplerin bu şekilde toplanması, drenaj yataklarındaki floraya zarar vermekte ve bu da nehrin doğal yoldan kendini temizlemesini önlemektedir (Rodrigues ve Maciel, 2017: 459).

Zaman zaman da olsa akarsuyun kirlenmesinde etkili olan unsurlardan bir diğeri de petrol boru hatlarında yaşanan kazalardır. Nitekim 2016 yılının ocak ve şubat aylarında Peru'nun ana petrol boru hattının yakınlarında yağışlar nedeniyle meydana gelen bir heyelan, iletim hattında bir sızıntıya ve ardından da patlamaya sebep olmuştur. Bunun sonucunda yine yağışların da etkisiyle yaklaşık 3.000 varil ham petrol, Maranon Nehri'nin kollarından Chiriaco ve Morona'ya karışmıştır. Meydana gelen bu olaydan söz konusu akarsulara bağlı olarak yaşamını sürdüren insan vd. canlılar, büyük zarar görmüştür (URL 37).

Havzada sürdürülebilir sosyoekonomik kalkınmayı tehdit eden unsurlardan dördüncüsüyse, havzanın kimi yerlerinde zaman zaman tesirini iyice artıran kuraklıklardır. Bundaysa; El Nino Güney Salınımı'nın, Tropikal Kuzey Atlantik'in anormal derecede ısınmasının ve küresel çapta yaşanan iklim değişikliğinin etkisi söz konusudur.

Nitekim Amazon ve diğer tropikal bölgelerdeki iklim aşırılıklarının ana nedeni olan El Nino Güney Salınımı, Doğu Pasifik Ekvatoral Bölgesi'ndeki deniz yüzeyinin aşırı ısınması ve buna bağlı olarak meydana gelen atmosferik olayların genel adıdır. El Nino Amazon'da etkisini genellikle; havzanın doğusunda kuraklık, batısındaysa alışılmadık bir yağış şeklinde göstermektedir. El Nino olayları 1982/1983, 1997/1998 ve 2015/2016 dönemlerinde havzada etkili olmuştur. Bunlardan özellikle 1997/1998 döneminde yüzey sıcaklıkları, rekor düzeyde gerçekleşmiştir. Bununla birlikte küresel ve bölgesel ısınma eğilimiyle birleştiği takdirde El Nino olayının, muhtemelen Amazon'da eşi benzeri görülmemiş kuraklıklara sebep olacağı tahmin edilmektedir (JiménezMuñoz vd., 2016: 1).

2005 yılında, Amazon'un GB'sindeki geniş sahalar, son yüz yılın en kurak dönemlerinden birini yaşamıştır. Bu kuraklıktan özellikle Amazon'un ana yatağı ile batı ve GB kolları (Madeira gibi) boyunca yaşayan insanlar, ciddi bir şekilde etkilenmiştir. 1926, 1983 ve 1998 yıllarındaki El Nino olaylarından farklı olarak bu kuraklık, orta ya da doğu Amazon'u etkilememiştir. Çünkü bu kuraklık El Nino Güney Salınımı'ndan değil, tropikal Kuzey Atlantik'in anormal derecede ısınmasından kaynaklanmıştır. Buna bağlı olarak gelişen atmosferik olaylar, yaz mevsimi boyunca 
Güney Amazon'un iç kısımlarında yağış miktarının azalmasına sebep olmuştur. Nemin normalden daha düşük ve hava sıcaklığının da 3 ilâ $5{ }^{\circ} \mathrm{C}$ daha yüksek olması nedeniyle 2005 yılının eylül ayında kuraklık, etkisini iyice hissettirmiştir. Bu süreçte nehir seviyesi oldukça düştüğünden sözü edilen akarsular üzerindeki seyirler, askıya alınmıștır. Ayrıca kurak mevsimin uzaması nedeniyle Amazon'un GB'sinde orman yangınları da çıkmıștır. Yağmurlar, 2005 yılının ekim ayından itibaren tekrar başlamış, fakat bu kez de 2006 yılının şubat ayından itibaren taşkınlar meydana gelmiştir (Marengo vd., 2008: 495).

Yine tropikal Atlantik'teki su sıcaklığının normalin çok üzerinde artması nedeniyle 2010 yılında yağış kuzeye doğru kaymış ve bu da havzanın geniş bir kısmında ciddi bir kuraklık yaşanmasına sebep olmuştur. Buna bağlı olarak 3 Aralık 2010 tarihinde nehrin en büyük kollarından biri olan Negro'nun Amazon'a dâhil olduğu Manaus şehri limanında derinlik, 13,63 m gibi rekor bir seviyeye düşmüştür. $\mathrm{Bu}$ da; yeme-içme, geçinme ve ulaşım bakımından nehre bağımlı olan insanlara büyük zarar vermiştir. Aynı zamanda düşük nem ve yüksek sıcaklık, kuraklığa eşlik ederek geniş çaplı yangınlara ve bu da kötü hava kalitesine yol açmıştır. Yine bu dönemde Manaus'un KB'sinde Negro Nehri'nin suyunun azalması nedeniyle örgülü kanalların birçoğu da ortadan kaybolmuştur (URL 38).

2010 yılında yaşanan bu kuraklıkta Amazon Nehri'nin, 1902 yılından beri en düşük seviyesine ulaştığı kaydedilmiştir. Bunun sonucunda; milyonlarca balık telef olmuş, binlerce kişi gıda sıkıntısıyla karşı karşıya kalmış, insanların temiz suya ulaşması zorlaşmış ve yetiştirilen tarım ürünleri de zarar görmüştür (URL 39).

Çeşitli sebeplere bağlı olarak havzada yaşanan bu kuraklıklar, yukarıda da değinildiği üzere zaten hızla tahrip edilen tropikal yağmur ormanlarının daha da azalmasına sebep olmaktadır. Gerçekten de kurak geçen dönemlerde başta en heybetlileri olmak üzere ağaç ölümlerinin arttı̆̆l, bilim insanlarının dikkatini çekmiştir. Bunun üzerine konuyla ilgili yapılan bir araştırma, yüksek bir boya ve geniş bir çapa sahip olan ağaçların daha çabuk ölmesinde, onların sistematik bozulmalara karşı daha hassas ve savunmasız olmasının etkili olduğunu ortaya koymuştur. Yine bu araştırmayla, kurak dönemde kökten doruklara doğru su taşıyan minik hücreli kanalların ağacın özündeki hava kabarcıkları tarafından tıkandığı ve bunun da bitkinin ölümüne sebep olduğu tespit edilmiştir (Rowland, vd., 2015: 119-122).

Havzada sürdürülebilir sosyoekonomik kalkınmayı tehdit eden unsurlardan beșincisiyse, zaman zaman Amazon ve kollarında görülen sel ve taşkınlardır. Nitekim aşırı hava olaylarının bir sonucu olarak 1984, 2001, 2009, 2012 ve 2014 yillarında havzada oldukça büyük seller meydana gelmiştir.

1984 ve 2001 yıllarındaki Amazon Nehri'nin ana akımında yaşanan büyük seller; başta Negro olmak üzere B, GB ve KB kollarındaki olağan dışı şubat ve nisan aylarındaki akış zirvelerinden kaynaklanmıştır. Her zamankine oranla tüm kollardan büyük miktarda eşzamanlı olarak su akışına sebep olan bu durum, Amazon Nehri'nin ana yatağındaki su hacmini artırarak Nisan-Mayıs aylarında Obidos şehrinde büyük bir sel baskınına sebep olmuştur (Ronchail vd., 2006: 220).

2009 yılında Brezilya'nın kuzeyinde aylar süren şiddetli yağışlar nedeniyle oluşan sel ve çamurlar, 186 bin kişiyi evsiz bırakırken 44 kişinin de ölümüne sebep olmuştur. Amazon bölgesinde kalan en az 7 eyalet, bölgede birkaç aydır süren şiddetli yağışlardan olumsuz bir şekilde etkilenmiştir. Ancak Atlantik kıyısındaki Maranhao, bu olaydan en kötü etkilenen eyalet olmuştur (URL 40).

2012 yılında Güney Atlantik'in daha serin ve Kuzey Atlantik'inse biraz daha sıcak olması, Amazon Havzası üzerinde mevsimsel atmosferik nem konverjansının ekim 2011 ile mayıs 2012 arasında normalin \% 38 daha üzerinde gerçekleşmesine neden olmuştur. Bunların bir sonucu olarak görülen yoğun yağışlar neticesinde havzada büyük bir sel meydana gelmiştir. Oluşan selde Negro 
Nehri üzerindeki Manaus Limanı'ndaki su seviyesi, 29 Mayıs tarihinde, 29,97 m gibi rekor bir değere ulaşmıştır. Bu, 2009 yılındaki bir önceki rekordan $20 \mathrm{~cm}$ daha yüksektir (Satyamurty vd., 2013: 1396).

2014 yılında yoğun yağışlar nedeniyle Negro Nehri, 22 Mayıs'tan haziran ayının sonuna kadar acil durum seviyesinin üzerinde bir akış göstermiştir. Buna bağlı olarak Manaus şehrinin kenarında, nehir boyunca igarapes olarak adlandırılan ve suya çok yakın yaşayan topluluklar, biriken pislik nedeniyle selden olumsuz etkilenmiștir. Sel suları, ahşap bungalovların altından aktığı için buradaki insanlar 30 ilâ 40 gün boyunca kirli sularla iç içe yaşamış ve bu durum, bulaşıcı hastalıklara sebep olmuştur. Amazonas eyaletinde 300.000'den fazla kişi etkilendiği bu selde, Careiro da Varzea gibi, kimi yerler bir aydan fazla sular altında kalmıștır. Yaşanan bu selde Negro, 2012 yılındaki zararın rekorunu da kırarak 91 milyon USD'den fazla hasara sebep olmuştur. Yine bu dönemde, Amazon'un en büyük kolu olan Madeira'da akış, rekor seviyelere ulaşmış ve kuzey Bolivya ile KB Brezilya'da son yüzyılın en kötü seli yaşanmıștır. Bütün bunların bir sonucu olarak Bolivya'da 60'dan fazla kişi ölürken Brezilya'daysa leptospirosis gibi bakteriyel enfeksiyonlar nedeniyle hayatını kaybedenler olmuştur (URL 41).

\section{TARTIŞMA VE SONUÇ}

Drenaj alanı ve deşarj bakımından dünyanın en büyük akarsuyu olan Amazon'un havzasında sürdürülebilir sosyoekonomik kalkınmayı tehdit eden unsurların neler olduğunu ortaya koymak amacıyla hazırlanan bu çalışmadan elde edilen bulgular ve bunlara ilişkin çözüm önerileri şunlardır:

Havzada sürdürülebilir sosyoekonomik kalkınmayı tehdit eden unsurlardan ilki, bölgesel güç olma iddiasındaki Brezilya başta olmak üzere, Amazon ülkelerinin adeta doğayla savaşırcasına bu nehir sisteminde devasa HES projelerini ya yapmış olmaları ya da yapmak istemeleridir. Nitekim havzada hem çok sayıda hem de büyük ölçekte yapılan barajlar, ormanlık alanları sular altında bırakarak buraları hem metan gazı üreten ve hem de salan yerler haline getirmektedir. Bu da sadece söz konusu havzanın ekosistemini değil, aynı zamanda iklim açısından bütün dünyanın geleceğini olumsuz bir şekilde etkileyebilecek bir durumdur. Aynı zamanda havzada inşa edilen bu barajlar yüzünden on binlerce insan da yerinden olmuştur. Bu nedenle Amazon Havzası'ndaki ülkelerin mümkün olduğunca devasa baraj inşa etmekten kaçınması gerekmektedir. Bunun yerine hem çevreye ve insanlara olumsuz etkileri daha az olan, hem de yerel ölçekte enerji ve su ihtiyacını karşılayan küçük baraj projelerine odaklanılması, yerinde olacaktır.

Ayrıca devasa barajların çevreye ve insana zararlarından başka maliyetleri de oldukça yüksektir. Bu nedenle havza ülkelerinin, HES odaklı enerji stratejilerini bir kez daha gözden geçirmelerinde büyük fayda vardır. Nitekim bu açıdan havza ülkelerinin, hem daha hızlı faaliyete geçirilebilen ve hem de daha verimli olan, güneş ve rüzgâr gibi enerji kaynaklarına ağırlık vermeleri yerinde olacaktır.

Bunun yanında Brezilya'nın elektrik sektörüyle ilgili yapılan teknik çalışmalar ülkenin, her türlü enerjiyi korumasının ve daha verimli kullanmasının gerekli olduğunu da göstermiştir (Filho, 2000, 2). Aynı durum Peru için de geçerlidir. Nitekim bu ülke de yüksek sosyal ve çevresel etkiler nedeniyle pahalı, riskli ve toplumsal uzlaşı sağlanamayan barajlar inşa etmek yerine elektrik üretimi ve enerji tasarrufu için daha ileri teknolojilere öncelik verebilir.

Havzanın geleceği açısından çok tehlikeli bir durum da baraj lisanslarının, siyasi baskı ve müdahaleler neticesinde onaylanmasıdır. Oysaki bu tür altyapı projeleriyle ilgili rasyonel bir karar verebilmek için, barajların neden olacağı olumlu ve olumsuz sonuçların çok iyi araştırılması gerekmektedir (Fearnside, 2014: 264-265). Araştırma sonucunda elde edilen çevresel ve sosyal 
etkilere göre de ilgili kuruluşların projenin onaylanıp onaylanmamasına bağımsız bir şekilde karar verebilmesi, havzadaki kalkınmanın sürdürülebilirliği açısından önemlidir.

Havzada sürdürülebilir sosyoekonomik kalkınmayı tehdit eden faktörlerden ikincisi, Amazon'un akarsu sistemi açısından hayati öneme sahip olan yağmur ormanlarına verilen zarardır. Nitekim inşa edilen barajların gerisinde biriken suların altında kalarak, tarım alanı açmak maksadıyla yangınlar çıkarılarak, maden sahası açılarak, yasal olan veya olmayan bir şekilde kesilerek bu ormanların kapladığı alan giderek azalmaktadır. Bu gidişle dünyanın akciğerleri olarak nitelendirilen Amazon Yağmur Ormanları'nın önemli bir kısmının yarım asra kadar yok olması işten bile değildir.

Başta soya monokültürü olmak üzere çeşitli tarım ürünlerini yetiştirmek ve et endüstrisi için sığır çiftlikleri açmak amacıyla havzadaki yağmur ormanları büyük bir tahribata uğramaktadır. Bu da; habitat yıkımları ve türlerin yok edilmesi gibi daha pek çok çevre felaketine sebep olmaktadır. Dolayısıyla tüm bunlara sebep olan küresel fast food șirketlerinin havzadaki faaliyetlerinin, biran önce kontrol altına alınması, havzanın geleceği açısından büyük önem arz etmektedir.

Dahası yağmur bulutlarını çekerek; kuraklık ve buna bağlı olarak görülen pek çok çevre felaketini önleyen ormanlar, su kaynaklarının beslenmesi ve korunmasında da büyük bir öneme sahiptir. $\mathrm{Bu}$ nedenle ormanların korunup geliştirilmesi, Amazon Nehri Havzası'ndaki kalkınmanın sürdürülebilirliği açısından da hayati öneme sahiptir.

Havzada sürdürülebilir sosyoekonomik kalkınmayı tehdit eden unsurlardan üçüncüsü, kirliliktir. $\mathrm{Bu}$ problemeyse daha çok madencilik faaliyetleri sebep olmaktadır. Zira kalkınma hızlarını artırabilmek için havza ülkeleri, büyük ölçekli maden projelerine vergi teşvikleri sağlamaktadır. Ancak bu faaliyetler sadece orman alanlarını tahrip etmekle kalmamakta, aynı zamanda gerek madencilik sahası çevresinde ve gerekse ekstraksiyon işlemlerinin akış aşağısında, doğaya birtakım zararlar da vermektedir (URL 31). Dahası sahada, büyük şirketler dışında binlerce de küçük ölçekli ve çoğunluğu yasadışı faaliyet gösteren maden işletmesi bulunmaktadır. Madencilik faaliyetlerinin yaygınlaşması havzada; ormansızlașmayı, toprak erozyonunu ve nehirlerdeki tortu seviyesini artırmaktadır. Ayrıca altın madenciliğinde kullanılan cıvanın da, hava ve suyu kirleterek besin zincirine girme riski vardır (Asnera vd., 2013: 18.456-18.457). Bu nedenle özellikle yasadışı madencilik faaliyetlerinin kontrol altına alınması, havzanın geleceği açısından büyük önem arz etmektedir.

Madencilik faaliyetinden başka Amazon Nehir Sistemi üzerinde; şehirlerden bırakılan atıkların, sanayi alanlarından salınan kirleticilerin ve tarım alanlarından dâhil olan kimyasalların da olumsuz etkileri söz konusudur.

Su kaynaklarındaki kirliliğin önlenebilmesi için; coğrafi bilgi sistemleri (CBS) kullanılarak akarsu kirlilik verilerinin toplanması, sayısal ortamda depolanması, konumsal analizlere olanak sağlayacak şekilde sorgulanması ve bunların zararlarını ortadan kaldırmak için gerekli takibin yapılması son derece önemlidir (Gümrükçüoğlu ve Baştürk, 2008). Ayrıca Manaus'ta olduğu gibi havza nehirleri üzerinde yer alan şehirlerdeki çöp problemleri ve bunlara bağlı olarak görülen sorunlar, ancak iyi planlanmış kanalizasyon toplama ve arıtma sistemlerinin kurulumu veya mevcut olanların da aynı şekilde modernizasyonuyla çözülebilir (URL 35).

Havzada sürdürülebilir sosyoekonomik kalkınmayı tehdit edebilecek bir diğer faktör, havzanın kimi yerlerinde zaman zaman tesirini iyice artıran kuraklıklar ile aşırı hava olaylarının bir sonucu olarak görülen sel ve taşkınlardır.

Amazon ve diğer tropikal bölgelerdeki iklim aşırılıklarının ana nedeni, El Nino Güney Salınımı'dır. El Nino Amazon'da etkisini genellikle; havzanın doğusunda kuraklık, batısındaysa alışılmadık bir 
yağış şeklinde göstermektedir (Jiménez-Muñoz vd., 2016: 1). Bununla birlikte son yıllarda Amazon Havzası'nda aşırı hava olaylarının görülme sıklığında bir artış da yaşanmaktadır. İklim değişikliğinin göstergelerinden biri olan bu durum nedeniyle havzada her sene; ya rekor bir kuraklık, ya da rekor bir sel meydana gelmektedir (URL 41).

Sel ve taşkınların yaratabileceği olumsuz etkileri azaltmak için öncelikle havza bazında yönetimi esas alan taşkın tehlike risk haritaları ile taşkın riski yönetim planlarının hazırlanması gerekmektedir (European Commission, 2007). Hazırlanan bu veriler ışığında da özellikle havzadaki kentsel alanlarda, taşkına sebep olan veya taşkın zararını artıran antropojenik faktörler, en aza indirilmeli ya da tamamen ortadan kaldırılmalıdır (Andrade vd., 2017: 52-53). Bu kapsamda Amazon Nehri Havzası'nı paylaşan ülkeler arasında ortak bir işbirliği ve yönetim programı da oluşturulabilir (Ríos-Villamizar, vd., 2017: 81).

Havzadaki hem küresel ve bölgesel ısınmanın hem de sel ve taşkın gibi afetlerin etkilerini kırabilmek için, yukarıda da değinildiği üzere öncelikle atmosfere önemli miktarda metan gazı salınımına sebep olan tropikal yağmur ormanlarının bulunduğu bölgelerde, çevresel açıdan yıkıma sebep olacak barajların inşasına bir kısıtlama getirilmesi şarttır. Bundan başka bir yandan büyük miktarlarda karbon depolayarak atmosferdeki ısınmanın yavaşlamasına, öte yandan da yağışın toprağa düşüşünü ve suyun yüzeysel akış hızını yavaşlatarak sel ve taşkın riskini önemli ölçüde azalttığı bilinen ormanlık alanlara çeşitli gerekçelerle zarar vermekten vaz geçilmesi gerekmektedir. Ayrıca et endüstrisini daha kârlı hale getirmek için Amazon Yağmur Ormanları'nda tarla açmaya bir son verme, enerji üretiminde HES'lerden ziyade güneş ve rüzgâr gibi diğer yenilenebilir enerji kaynaklarına yönelme, enerjiyi koruma ve daha verimli kullanma gibi hususlara ağırlık verme de bu hususta havzada alınabilecek diğer önlemlerdir.

Sonuç olarak, inceleme alanındaki kalkınma sürdürülebilirlik açısından değerlendirilecek olursa, Amazon Nehri Havzası'nda biyosferin insan faaliyetlerinin zararlı etkilerini emme kabiliyetinin sınırlarına ulaştığını ve artık dengenin bariz bir şekilde doğanın aleyhine olacak şekilde bozulmaya başladığını söylemek mümkündür. Bunun bir sonucu olarak havzada, doğanın ikazı mahiyetinde, birtakım olumsuz olaylar yaşanmaya başlamıştır. Çok geç olmadan bu uyarılar dikkate alınmazsa; sadece gelecek nesillerin kendi ihtiyaçlarını karşılama yeteneği ellerinden alınmakla kalmayacak, aynı zamanda şimdiki nesil de afetler yoluyla çevreye verilen tahribatın zararlı sonuçlarına daha belirgin bir şekilde maruz kalmaya başlayacaktır. Afetlerin sebep olacağı can ve mal kayıpları da, bilinçsizce yapılan yatırımların getirisini boşa çıkaracak ve bu da havzadaki kalkınmayı olumsuz bir şekilde etkileyecektir. Dolayısıyla havza ülkelerinin, sürdürülebilir bir sosyoekonomik büyüme için, kalkınma stratejilerini çok geç olmadan tekrar gözden geçirmelerinde büyük fayda vardır.

\section{KAYNAKLAR}

Aguirre, M. (2014). What Future for Peru's Marañón River?. World Rivers Review, Volume: 29, No: 2, 7.

Amazon Institute for Environmental Research. (2017). A Pathway to Zero Deforestation in the Brazilian Amazon. Belem: IPAM.

Andrade, M.M.N., Bandeira, I.C.N., Fonseca, D.D.F.,Bezerra, P.E.S., Andrade, A.S., Oliveira, R.S. (2017). Flood Risk Mapping in the Amazon. Flood Risk Management, 41-54. Rijeka: Intech.

Asnera, G. P., Llactayob, W., Tupayachia, R., Lunac, E. R. (2013). Elevated rates of gold mining in the Amazon revealed through high-resolution monitoring. Proceedings of the National Academy of Sciences, 110(46), 18454-18459. doi: 10.1073/pnas.1318271110

Contos, J. and Tripcevich, N. (2014). Correct placement of the most distant source of the Amazon River in the Mantaro River drainage. Area, 46(1), 27-39. doi: 10.1111/area.12069 
do Nascimento, F. S. (2015). Manejo Integrado e Sustentável Dos Recursos Hídricos Transfronteiriços Da Bacia Do Rio Amazonas Considerando a Variabilidade e a Mudança Climática. Brasília: OTCA, GEF, PNUMA.

Ertek, A. (1991). Amerika. İslâm Ansiklopedisi. 3, 30-37. Ankara: TDV İSAM.

European Commission. (2007). Directive 2007/60/EC of the European Parliament and of the Council of 23 October 2007 on the assessment and management of flood risks. Official Journal of the European Union, 15(1), 27-34.

Fearnside, P. M. (1989). Brazil's Balbina Dam: Environment versus the legacy of the Pharaohs in Amazonia. Environmental Management, 13(4), 401-423. doi: 10.1007/BF01867675

Fearnside, P. M. (1991). Environmental Destruction Social in the Brazilian Amazon, Hall A. and Goodman, D. (Ed.). The Future of Amazonia: Destruction or Sustainable Development? Springer, 1.

Fearnside, P. M. (2005), Brazil's Samuel Dam: Lessons for Hydroelectric Development Policy and the Environment in Amazonia. Environmental Management, 35(1), 1-19. doi: 10.1007/s00267-004-0100-3

Fearnside, P. M. (2006). Dams in the Amazon: Belo Monte and Brazil's Hydroelectric Development of the Xingu River Basin. Environmental Management 38(1), 16-27. doi: 10.1007/s00267-005-00113-6

Fearnside, P. M. (2014). Viewpoint-Brazil's Madeira River Dams: A Setback for Environmental Policy in Amazonian Development. Water Alternative, 7(1), 256-269.

Fearnside, P. M. (2015). Amazon dams and waterways: Brazil’s Tapajós Basin plans. Ambio, 44(5), 426439. doi: $10.1007 / s 13280-015-0642-z$

Fearnside, P. M. (2015). Brazil's São Luiz do Tapajós Dam: The Art of Cosmetic Environmental Impact Assessments. Water Alternatives, 8(3), 373-396.

Filho, H. M. (2000). Steps taken in the Brazilian Energy and Transportation Sectors that contribute to the ultimate objective of the UNFCCC. Workshop on Best Practices in Policies and Measures, Copenhagen, 1-10.

Global Witness. (2016). 2015's Deadly Environment: The Killing And Criminalization Of Land And Environmental Defenders Worldwide. London.

Goulding, M., Barthem R., Ferreira, E. (2003). The Smithsonian Atlas of the Amazon. Washington: Smithsonian Books.

Guyot, J. L., Bazan, H., Fraizy, P., Ordonez, J. J., Armijos, E. \& Laraque, A. (2007). Suspended sediment yields in the Amazon Basin of Peru: A first estimation. Water Quality and Sediment Behaviour of the Future: Predictions for the 21st Century, IAHS Publications: 314.

Gümrükçüoğlu, M. ve Baştürk, O. (2008, Mart). Sürdürülebilir Su Yönetiminde Nehir Kirliliği Üzerine Bir Çalışma. TMMOB 2. Su Politikaları Kongresi, Ankara.

Jiménez-Muñoz, J. C., Mattar, C., Barichivich, J., Santamaría-Artigas, A., Takahashi, K., Malhi, Y., Sobrino, J. A., van der Schrier, G. (2016). Record-breaking warming and extreme drought in the Amazon rainforest during the course of El Niño 2015-2016. Scientific Reports, 6(33130). doi: 10.1038/srep33130 (2016)

Karaman, A. (1996). Sürdürülebilir Turizm Planlaması İçin Ekolojik Bir Çerçeve. Sürdürülebilir Turizm; Turizm Planlamasına Ekolojik Yaklaşım, 19. Dünya Şehircilik Günü Kolokyumu, Mimar Sinan Üniversitesi, İstanbul.

Kemenes, A., Forsberg, B. R., Melack, J. M. (2007). Methane release below a tropical hydroelectric dam. Geophysical Research Letters, 34(12), 1-5. doi: https://doi.org/10.1029/2007GL029479 
Linhares, D. P., da Silva, J. M., Lima, T. R., de Oliveira, R. C., de Oliveira Gomes, J. P., Bastos, W. R., da Silveira, E. G. (2005). Mercury Concentration In Margin Soil Of The Madeira River. Sociedade \& Natureza, 369-379.

Marengo, J. A., Nobre, C. A., Tomasella, J. (2008). The Drought of Amazonia in 2005. Journal of Climate, 21, 495-516. doi: https://doi.org/10.1175/2007JCLI1600.1

Özmehmet, E. (2012). Dünyada ve Türkiye Sürdürülebilir Kalkınma Yaklaşımları. Journal of Yaşar University, $3(12), 1-23$.

Padmalal, D., Maya, K. (2014). Sand Mining: Environmental Impacts and Selected Case Studies. Dordrecht: Springer.

Perez, M. S. (2015). Where the Xingu Bends and Will Soon Break. American Scientist, 103(6), 395-403. doi: $10.1511 / 2015.117 .395$

Pfeiffer, W. C., Malm, O., Souza, C. M., Lacerda, L. D., da Silveira, E. G., Bastos, W. R. (1991). Mercury in the Madeira River ecosystem, Rondonia, Brazil. Forest Ecology and Management, 38, 239-245. doi: https://doi.org/10.1016/0378-1127(91)90145-L

Rafferty, J. P. (Ed.), (2011). Rivers and Streams. New York: The Rosen Publishing Group.

Ray, G. C., McCormick-Ray, J. (2004). Coastal-Marine Conservation: Science and Policy. Blackwell Publishing.

Ríos-Villamizar, E. A., Piedade, M. T. F., Junk, W. J., Waichman, A. V. (2017). Surface Water Quality and Deforestation of the Purus River Basin, Brazilian Amazon. International Aquatic Research, 9(1), 81-88. doi: https://doi.org/10.1007/s40071-016-0150-1

Rodrigues, L. M. S. P. \& Maciel, J. S. C., (2017). The Use of Naturel Fiber as a Barrier to Garbage in Amazon Urban Rivers, Brebbia, C.A., Longhurst, J., Marco, E., Booth, C. (Ed.). Sustainable Development and Planning IX. WIT Press.

Ronchail, J., Guyot, J. L., Espinoza Villar, J. C., Fraizy, P., Cochonneau, G., De Oliveira, E., Filizola, N., Ordenez, J. J. (2006). Impact of the Amazon tributaries on major floods at Óbidos, Climate Variability and ChangeHydrological Impacts, IAHS Publication: 308.

Rosa, L. P., dos Santos, M. A., Matvienko, B., dos Santos, E. O., Sikar, E. (2004). Greenhouse Gas Emissions from Hydroelectric Reservoirs in Tropical Regions. Climatic Change, 66(1-2), 9-21. doi: https://doi.org/10.1023/B:CLIM.0000043158.52222.ee

Rowland, L., da Costa, A. C. L., Galbraith, D. R., Oliveira, R. S., Binks, O. J., de Oliveira, A. A. R., Pullen, A. M., Doughty, C. E., Metcalfe, D., Vasconcelos, S. S., Ferreira, L. V., Malhi, Y., Grace, J., Mencuccini, M., Meir, P. (2015). Death from drought in tropical forests is triggered by hydraulics not carbon starvation. Nature, 528(7580), 119-122. doi: 10.1038/nature15539

Sailing Directions. (2004). East Coast of South America Enroute. Los Angeles Culver City: ProStar Publications.

Santini, W., Martinez, J. M., Espinoza-Villar, R., Cochonneau, G., Vauchel, P., Moquet, J. S., Baby, P., Espinoza, J. C., Lavado, W., Carranza, J. \& Guyot, J. L. (2014). Sediment budget in the Ucayali River basin, an Andean tributary of the Amazon River. Sediment Dynamics from the Summit to the Sea, IAHS Publications: 367, 320325. doi:10.5194/piahs-367-320-2015

Satyamurty, P., da Costa, C. P. W., Manzi, A. O., Candido, L. A. (2013). A quick look at the 2012 record flood in the Amazon Basin. Geophysical Research Letters, 40(7), 1396-1401. doi: https://doi.org/10.1002/grl.50245

Tollefson, J. (2011). A struggle for power. Nature, No: 479, 160-161. doi: https://doi.org/10.1038/479160a 
Tolunay, A., Akyol A. (2006). Kalkınma ve Kırsal Kalkınma: Temel Kavramlar ve Tanımlar. Süleyman Demirel Üniversitesi Orman Fakültesi Dergisi, A(2), 116-127.

UNEP \& IBAMA. (2002). Geo Brazil 2002. Brasilia: IBAMA Editions.

UNEP. (2010). Waste and Climate Change: Global Trends and Strategy Framework. Osaka/Shiga: UNEP Division of Technology, Industry and Economics International Environmental Technology Centre.

URL 1, https://sustainabledevelopment.un.org/content/documents/5987our-common-future.pdf, (Son Erişim: 07.05.2020)

URL 2, https://www.newworldencyclopedia.org/entry/Amazon River, (Son Erișim: 07.05.2020)

URL 3, https://earthobservatory.nasa.gov/images/7021/amazon-river-in-the-atlantic-ocean, (Son Erişim: 07.05.2020)

URL 4, https://www.internationalrivers.org/campaigns/mara\%C3\%B1\%C3\%B3n-river, (Son Erișim: 07.05.2020)

URL 5, https://www.internationalrivers.org/campaigns/tapaj\%C3\%B3s-basin, (Son Erişim: 07.05.2020)

URL 6, https://www.esbr.com.br/a-usina\#caracteristicas, (Son Erişim: 07.05.2020)

URL 7, https://www.santoantonioenergia.com.br/hidreletrica-santo-antonio-gerou-34-milhoes-demegawatts-hora-em-cinco-anos-de-operacao/, (Son Erişim: 07.05.2020)

URL

https://www.copel.com/uhecolider/noticia.jsp?not=\%2Fuhecolider\%2Fpagcopel2.nsf\%2Fdocs $\% 2 F 49 \mathrm{~A} 1$ B99451B76E56032578B00068AD22, (Son Erişim: 07.05.2020)

URL 9, https://www.theguardian.com/global-development/2016/jun/15/brazil-giant-hydropower-damsrisk-destroying-amazon-greenpeace-tapajos-river, (Son Erişim: 07.05.2020)

URL 10, http://dams-info.org/pt/dams/view/sao-luiz-do-tapajos/, (Son Erișim: 07.05.2020)

URL 11, https://www.theguardian.com/environment/2013/apr/03/brazil-dam-activists-war-military, (Son Erişim: 07.05.2020)

URL 12, https://www.greenpeace.org/brasil/blog/hidreletrica-no-tapajos-esta-cancelada/, (Son Erişim: 07.05.2020)

URL 13, http://dams-info.org/pt/dams/view/jatoba/, (Son Erişim: 07.05.2020)

URL 14, http://dams-info.org/pt/dams/view/chacorao/ (Son Erişim: 07.05.2020)

URL 15,

http://www2.aneel.gov.br/aplicacoes/Contrato/Documentos_Aplicacao/Contrato\%20Belo\%20Monte.pdf (Son Erişim: 07.05.2020)

URL 16, https://medium.com/greenpeace/in-brazil-dams-threaten-rivers-the-environment-and-peopleslives-d748f2f20288, (Son Erişim: 07.05.2020)

URL 17, https://www.bbc.com/news/world-latin-america-38391377, (Son Erişim: 07.05.2020)

URL 18, https://www.dw.com/en/concerns-about-methane-plague-brazils-belo-monte-dam/a-15367464, (Son Erişim: 07.05.2020)

URL 19, https://www.evrensel.net/haber/257207/brezilyanin-yerli-amazonlari-belo-monte-barajialtinda-eziliyor, (Son Erişim: 07.05.2020) 
URL 20, https://www.theguardian.com/world/2016/apr/08/brazil-rousseff-corruption-belo-montedam?CMP=twt a-environment b-gdneco, (Son Erișim: 07.05.2020)

URL 21, https://ustr.gov/trade-agreements/free-trade-agreements/peru-tpa, (Son Erişim: 07.05.2020)

URL 22,

https://www.sabah.com.tr/dunya/2009/11/16/peruda yagmur ormani_savasini yerliler kazandi, (Son Erişim: 07.05.2020)

URL 23, http://www.radikal.com.tr/dunya/amazonlarda-perunun-tiananmen-meydani-939975/, (Son Erişim: 07.05.2020)

URL 24, http://www.radikal.com.tr/yorum/perulu-yerlilerin-enerji-yasasina-isyani-939496/, (Son Erişim: 07.05.2020)

URL 25, https://www.internationalrivers.org/resources/peru-brazil-energy-agreement-challenged-inperu-court-3688, (Son Erişim: 07.05.2020)

URL 26, https://www.internationalrivers.org/resources/9022, (Son Erişim: 07.05.2020)

URL 27, https://www.internationalrivers.org/resources/new-maps-project-potential-flooded-areas-ofdams-in-the-mara\%C3\%B1\%C3\%B3n-river-basin-8271, (Son Erișim: 07.05.2020)

URL 28, https://www.popsci.com/environmental-damage-amazon-river-dams/, (Son Erişim: 07.05.2020)

URL 29, $\quad$ https://www.hoddereducation.co.uk/media/Documents/Geography/MRN-AQA-GCSEGeography-EP-answers.pdf?ext=.pdf, (Son Erişim: 03.11.2020)

URL 30, http://www.mightyearth.org/mysterymeat/, (Son Erişim: 07.05.2020)

URL 31,

https://wwf.panda.org/knowledge hub/where we work/amazon/amazon threats/other_threats/amazo n_mining/, (Son Erişim: 07.05.2020)

URL 32, https://tr.euronews.com/2017/09/26/amazon-ormanlari-kurtuldu, (Son Erişim: 07.05.2020)

URL 33, https://www.bbc.com/turkce/haberler-dunya-40104764, (Son Erişim: 07.05.2020)

URL 34, https://daac.ornl.gov/cgi-bin/dsviewer.pl?ds_id=1153, (Son Erişim: 09.10.2020)

URL 35, https://www.reuters.com/article/us-brazil-environment-mining-insight/amazons-billion-dollargold-rush-leaves-trail-of-toxins-idUSKBN19K1CG, (Son Erişim: 07.05.2020)

URL 36, https://www.americasquarterly.org/content/garbage-choking-amazons-biggest-city, (Son Erişim: 07.05.2020)

URL 37, https://www.reuters.com/article/us-peru-oil-spill/peru-pipeline-leaks-in-amazon-two-riverspolluted-agency-says-idUSKCN0VW064, (Son Erişim: 07.05.2020)

URL 38, https://earthobservatory.nasa.gov/images/47693/brazils-negro-river-reaches-record-low, (Son Erişim: 07.05.2020)

URL 39, $\quad$ https://www.ntv.com.tr/dunya/amazon-nehri-100-yilin-en-dusukseviyesinde,8I6KQyVDUEei65JnepS7ig, (Son Erişim: 07.05.2020)

URL 40, $\quad$ https://www.abc.net.au/news/2009-05-10/44-dead-126000-homeless-in-brazilfloods/1677842, (Son Erişim: 07.05.2020) 
URL 41, https://www.bbc.com/news/world-latin-america-28123680, (Son Erişim: 07.05.2020)

USGS. (1967). The Amazon, measuring a mighty river. Washington: U.S. Government Printing Office.

W. L. F. Brinkmann (1986). Particulate and Dissolved Materials in the Rio Negro Amazon. Sediments and Water Interactions: Proceedings of the Third International Symposium on Interactions Between Sediments and Water. Geneva.

Winemiller, K. O. and Willis, S. C. (2011). The Vaupes Arch and Casiquiare Canal, J. S. Albert, R. E. Reis (Ed.) Historical Biogeography of Neotropical Freshwater Fishes. University of California Press.

WWF. (2014). 2014 The International Conservation Budget. Washington: WWF Publications.

Yeni, O. (2014). Sürdürülebilirlik ve Sürdürülebilir Kalkınma: Bir Yazın Taraması. Gazi Üniversitesi İktisadi ve İdari Bilimler Fakültesi Dergisi, 16(3), 181-208. 